\title{
Water column biogeochemistry of oxygen minimum zones in the eastern tropical North Atlantic and eastern tropical South Pacific oceans
}

\author{
Carolin R. Löscher ${ }^{1, a}$, Hermann W. Bange ${ }^{1}$, Ruth A. Schmitz ${ }^{2}$, Cameron M. Callbeck ${ }^{3}$, Anja Engel ${ }^{1}$, Helena Hauss ${ }^{1}$, \\ Torsten Kanzow ${ }^{1, \mathrm{~b}}$, Rainer Kiko ${ }^{1}$, Gaute Lavik $^{3}$, Alexandra Loginova ${ }^{1}$, Frank Melzner ${ }^{1}$, Judith Meyer ${ }^{1}$, \\ Sven C. Neulinger ${ }^{2, \mathrm{c}}$, Markus Pahlow ${ }^{1}$, Ulf Riebesell ${ }^{1}$, Harald Schunck ${ }^{2}$, Sören Thomsen ${ }^{1}$, and Hannes Wagner ${ }^{1}$ \\ ${ }^{1}$ GEOMAR Helmholtz Centre for Ocean Research Kiel, Düsternbrooker Weg 20, 24105 Kiel, Germany \\ ${ }^{2}$ Institute of General Microbiology, Christian-Albrechts-Universität zu Kiel, Am Botanischen Garten 1-9, 24118 Kiel, \\ Germany \\ ${ }^{3}$ Max Planck Institute for Marine Microbiology, Celsiusstraße 1, 28359 Bremen, Germany \\ anow at: Nordic Center for Earth Evolution, Department of Biology, University of Southern Denmark, Campusvej 55, \\ 5230 Odense M, Denmark \\ ${ }^{\mathrm{b}}$ now at: AWI, Bremerhaven, Germany \\ ${ }^{c}$ now at: omics2view.consulting GbR, Kiel, Germany
}

Correspondence to: Carolin R. Löscher (cloescher@geomar.de)

Received: 22 January 2015 - Published in Biogeosciences Discuss.: 17 March 2015

Revised: 4 May 2016 - Accepted: 24 May 2016 - Published: 20 June 2016

\begin{abstract}
Recent modeling results suggest that oceanic oxygen levels will decrease significantly over the next decades to centuries in response to climate change and altered ocean circulation. Hence, the future ocean may experience major shifts in nutrient cycling triggered by the expansion and intensification of tropical oxygen minimum zones (OMZs), which are connected to the most productive upwelling systems in the ocean. There are numerous feedbacks among oxygen concentrations, nutrient cycling and biological productivity; however, existing knowledge is insufficient to understand physical, chemical and biological interactions in order to adequately assess past and potential future changes.

In the following, we summarize one decade of research performed in the framework of the Collaborative Research Center 754 (SFB754) focusing on climate-biogeochemistry interactions in tropical OMZs. We investigated the influence of low environmental oxygen conditions on biogeochemical cycles, organic matter formation and remineralization, greenhouse gas production and the ecology in OMZ regions of the eastern tropical South Pacific compared to the weaker OMZ of the eastern tropical North Atlantic. Based on our findings, a coupling of primary production and organic matter ex-
\end{abstract}

port via the nitrogen cycle is proposed, which may, however, be impacted by several additional factors, e.g., micronutrients, particles acting as microniches, vertical and horizontal transport of organic material and the role of zooplankton and viruses therein.

\section{Introduction}

Eastern boundary upwelling systems are ocean areas where cold and nutrient-rich waters are upwelled to the sea surface, where they fuel high biomass production (Carr, 2002; Chavez and Messie, 2009). While covering only $0.2 \%$ of the ocean, those upwelling areas account for about 50-58\% of global fish catch (Pauly and Christensen, 1995). Two eastern boundary upwelling systems were subject to this study: the upwelling off Mauritania, located in the eastern tropical North Atlantic (ETNA), and the upwelling system off Peru, located in the eastern tropical South Pacific (ETSP). While both systems are characterized by intense primary production, their biogeochemical properties differ strongly (Karstensen et al., 2008), which partially results from a combination of dif- 
ferent water mass ages and characteristics (Körtzinger et al., 2004), topography and atmospheric impacts (e.g., Duce et al., 2008). A major difference between the ETNA and the ETSP is the intensity of the oxygen minimum zone (OMZ) associated with those upwelling regions (Capone and Hutchins, 2013): the ETNA OMZ has $\mathrm{O}_{2}$ concentrations typically above $40 \mu \mathrm{mol} \mathrm{kg}^{-1}$, whereas the large and persistent OMZ in the ETSP located off Peru and Chile has $\mathrm{O}_{2}$ concentrations below the detection limit based on conventional methods $\left(\sim 2 \mu \mathrm{mol} \mathrm{kg}^{-1}\right.$, Fig. 1) with sometimes even sulfidic conditions on the shallower shelf (Schunck et al., 2013).

Besides the age of the water mass and other physical constraints, biological remineralization and respiration processes consume $\mathrm{O}_{2}$ below the highly productive surface waters and contribute to the development and maintenance of OMZ waters (Walsh, 1981; Quiñones et al., 2010). The intensity of the OMZ may be determined by a positive feedback, with increased primary production leading to enhanced organic matter export back to underlying $\mathrm{O}_{2}$-depleted waters (Dale et al., 2015). As a consequence of enhanced organic matter export, respiration processes may increase. Anoxia, on the other hand, would promote $\mathrm{O}_{2}$ sensitive $\mathrm{N}$ loss processes, creating a nitrogen $(\mathrm{N})$ deficit in upwelled waters. This would then stimulate $\mathrm{N}_{2}$ fixation at the sea surface and enhance again primary production. A critical issue to understand is to what extent a feedback between primary production, organic matter remineralization and the $\mathrm{N}$ cycle is a valid model in OMZ waters and what role sulfidic conditions play therein.

Modeling results (Bopp et al., 2013; Cocco et al., 2013) predict that $\mathrm{O}_{2}$ levels will decrease significantly over the next decades in response to climate change and eutrophication. Hence, the future ocean may experience major shifts in nutrient cycling triggered by the possible expansion and intensification of tropical OMZs (Codispoti, 2010). Currently, the estimated volume of OMZs with $\mathrm{O}_{2}$ concentrations $<20 \mu \mathrm{mol} \mathrm{kg}^{-1}$ is about $1 \%$ of the global ocean volume (Lam and Kuypers, 2011). Approximately $0.05 \%$ of the global ocean volume has $\mathrm{O}_{2}$ levels below $5 \mu \mathrm{mol} \mathrm{kg}{ }^{-1}$. The effects of $\mathrm{O}_{2}$-sensitive nutrient cycling processes occurring in these relatively small regions (Codispoti, 2010) are conveyed to the rest of the ocean (see, e.g., Deutsch et al., 2007). Hence, comparatively "small" volumes of OMZs can significantly impact nutrient budgets, biological productivity and the overall potential for $\mathrm{CO}_{2}$ fixation in the ocean. An important factor is further that deoxygenation of OMZs has been proposed to increase the production of the greenhouse gas nitrous oxide $\left(\mathrm{N}_{2} \mathrm{O}\right)$ (Codispoti, 2010). Therefore, understanding the present biogeochemistry of those systems and exploring the potential to respond to climate change is critical.

The following review of the major biogeochemical processes in OMZ waters is based on studies of the SFB754, "Climate-Biogeochemistry Interactions in the Tropical Ocean" (www.sfb754.de). Comparisons between the ETNA and ETSP upwelling systems, their OMZs, and differences in remineralization processes and associated marine sources and sinks of important nutrient elements are discussed in order to understand potential controls on the intensity of those OMZs, as well as their future development.

\section{Primary production in the ETSP and ETNA}

In eastern boundary upwelling systems, phytoplankton blooms are stimulated by nutrient supply from upwelled waters and provide the basis for vibrant ecological systems. Both the ETNA and the ETSP are major sites of primary production (Longhurst et al., 1995), with the ETNA exceeding primary production of the ETSP by a factor of $\sim 2$ depending on the applied method (see Table 1 for an overview of major primary production-related parameters). This difference may be explained, for example, by the stoichiometry of the macronutrients $\mathrm{N}$ and phosphate $(\mathrm{P})$, with the deficit of $\mathrm{N}$ based on a Redfieldian equilibrium of $\mathrm{N}: \mathrm{P}=16: 1$ being significantly stronger in the ETSP compared to the ETNA (Deutsch et al., 2007). This difference may be due to intensified $\mathrm{N}$ loss mirrored by a strongly positive $\delta^{15} \mathrm{~N}$-nitrate signal (Ryabenko et al., 2012) in the more $\mathrm{O}_{2}$-depleted water column and sediments of the ETSP. On the other hand, enhanced $\mathrm{P}$ release from the sediments at decreasing $\mathrm{O}_{2}$ (Ingall and Jahnke, 1994), or a difference between $\mathrm{N}$ and P remineralization from organic material (Jilbert et al., 2011), may impact decreased $\mathrm{N}: \mathrm{P}$ ratios. A stronger $\mathrm{N}$ deficit in the water column may influence primary production in different ways: it may stimulate $\mathrm{N}_{2}$ fixation in order to replenish the $\mathrm{N}$ deficit, or it may stimulate non-Redfield primary production. A way to detangle these potential responses is thus to understand the community composition.

Franz et al. (2012a) reported in situ observations along an east-west transect in the ETSP at $10^{\circ} \mathrm{S}$ stretching from the upwelling region above the narrow continental shelf to the well-stratified oceanic section of the eastern boundary regime. The study showed that new production in the coastal upwelling was driven by large-sized phytoplankton (e.g., diatoms) with generally low $\mathrm{N}$ : $\mathrm{P}$ ratios $(<16: 1)$, thus speaking for non-Redfield surface water primary production. A deep chlorophyll $a$ maximum consisting of nano(Synechococcus, flagellates) and microphytoplankton occurred within a pronounced thermocline in subsurface waters above the shelf break. Here, intermediate particulate $\mathrm{N}: \mathrm{P}$ ratios were close to Redfield proportions. High PON : POP $(>20: 1)$ ratios were observed in a stratified open-ocean section, coinciding with a high abundance of the picocyanobacterium Prochlorococcus. Excess $\mathrm{P}$ was present along the entire transect but did not appear to stimulate growth of $\mathrm{N}_{2}$ fixing cyanobacteria, as pigment fingerprinting and phylogenetic studies did not indicate the presence of diazotrophic cyanobacteria at most of our sampling stations (Franz et al., 2012a; Löscher et al., 2014). These findings are mostly in 


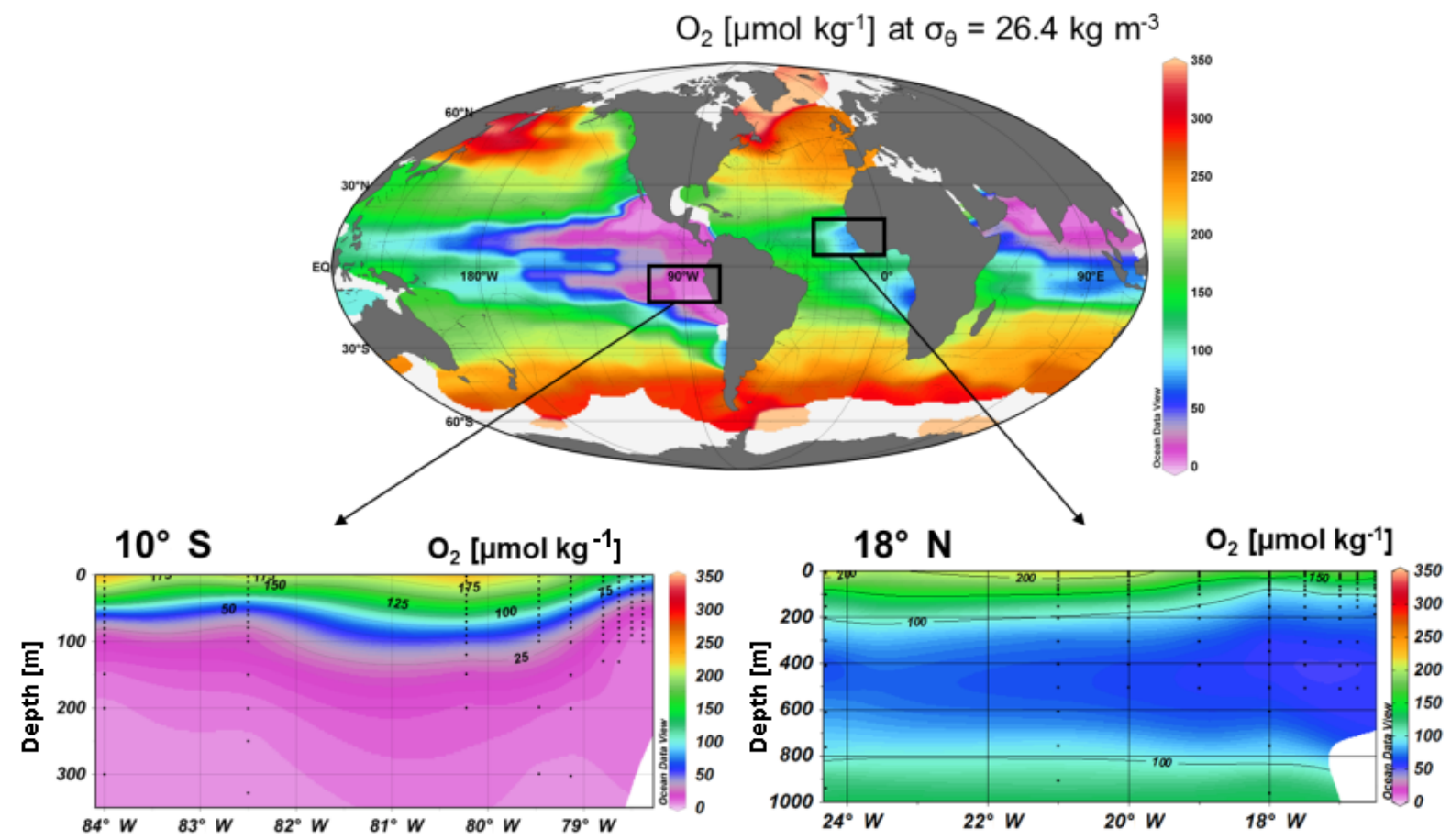

Figure 1. Global distribution of $\mathrm{O}_{2}$ at $\sigma_{\theta}=26.4 \mathrm{~kg} \mathrm{~m}^{-3}(\sim 400 \mathrm{~m}$ depth): the major regions of low oxygen in the world ocean are all located in the tropical oceans, at shallow to intermediate depths. The area off Peru represents one of the most pronounced OMZs. The investigated areas in the eastern tropical South Pacific and the eastern tropical North Atlantic oceans are marked with black boxes; examples of the $\mathrm{O}_{2}$ distribution are given along two sections from the coast to the open ocean at $10^{\circ} \mathrm{S}$ in the $\mathrm{OMZ}$ off Peru and at $18^{\circ} \mathrm{N}$ in the eastern tropical North Atlantic; $\mathrm{O}_{2}$ concentrations are indicated by the color code.

Table 1. A comparison of the $\mathrm{O}_{2}$ minimum, excess nitrogen $\left(\mathrm{N}^{*}\right)$, primary production, organic $\mathrm{C}$ export, $\mathrm{N}_{2}$ fixation and $\mathrm{N}$ loss in the ETNA and ETSP upwelling regions.

\begin{tabular}{|c|c|c|c|c|}
\hline & ETSP - shelf & ETSP - offshore & ETNA - shelf & ETNA - offshore \\
\hline $\mathrm{O}_{2} \min \left(\mu \mathrm{mol} \mathrm{kg} g^{-1}\right)$ & 0 (sulfidic) & 0 & 25 & 40 \\
\hline $\mathrm{N}^{*}\left(\mathrm{~mol} \mathrm{~m}^{-2}\right)$ & \multicolumn{4}{|l|}{-1.9 to $(-5.98)^{\mathrm{a}}$} \\
\hline Primary production $\left(\mathrm{mmol} \mathrm{C} \mathrm{m}{ }^{-2} \mathrm{~d}^{-1}\right)$ & $\begin{array}{l}101-122^{b} \\
68.5^{c} \\
61,4^{d}\end{array}$ & $73-94^{b}$ & \multicolumn{2}{|c|}{$\begin{array}{l}137^{\mathrm{c}} \\
167^{\mathrm{d}}\end{array}$} \\
\hline Organic $\mathrm{C}$ export $\left(\mathrm{mmol} \mathrm{C} \mathrm{m}^{-2} \mathrm{~d}^{-1}\right)$ & $10.6-75.3^{b}$ & $2.6-11.1^{b}$ & $6.4-9.3^{\mathrm{e}}$ & $0.67-2.6^{\mathrm{e}}$ \\
\hline $\mathrm{N}_{2}$ fixation $\left(\mu \mathrm{mol} \mathrm{N} \mathrm{m}^{-2} \mathrm{~d}^{-1}\right)$ & \multicolumn{2}{|c|}{$25-657^{\mathrm{f}}$} & \multicolumn{2}{|c|}{$24-140^{\mathrm{g}}$} \\
\hline $\begin{array}{l}\% \text { contribution of } \mathrm{N}_{2} \\
\text { fixation to primary production* }\end{array}$ & $\begin{array}{l}0.2-4^{b} \\
0.2-6.4^{c} \\
0.3-7.1^{d}\end{array}$ & & \multicolumn{2}{|c|}{$\begin{array}{l}0.2-0.7^{\mathrm{c}} \\
0.1-0.6^{\mathrm{d}}\end{array}$} \\
\hline $\begin{array}{l}\mathrm{N} \text { loss }\left(\mathrm{mmol} \mathrm{Nm}^{-2} \mathrm{~d}^{-1}\right) \\
\text { anammox denitrification }\end{array}$ & $\begin{array}{l}1-10 \text { to } 70 \\
\text { (in presence of } \mathrm{H}_{2} \mathrm{~S} \text { ) }\end{array}$ & $\begin{array}{l}0 \\
0\end{array}$ & $\begin{array}{l}0 \\
0\end{array}$ & \\
\hline
\end{tabular}

* Calculated based on the Redfield ratio of $\mathrm{C}: \mathrm{N}=106: 16$ using the primary production and $\mathrm{N}_{2}$ fixation rates given in this table in consistency with the \% contribution given in Duce et al. (2008). ${ }^{\text {a }}$ Kalvelage et al. (2013); ${ }^{\mathrm{b}}$ Dale et al. (2015); ${ }^{\mathrm{c}}$ Behrenfeld and Falkowski (1997); ${ }^{\mathrm{d}}$ Longhurst et al. (1995); ${ }^{\mathrm{e}}$ Iversen et al. (2010); ${ }^{\mathrm{f}}$ Dekaezemacker et al. (2013) and Löscher et al. (2014); ${ }^{\mathrm{g}}$ Voss et al. (2004). 
accordance with other studies from this area (Bonnet et al., 2013; Fernandez et al., 2011; Turk-Kubo et al., 2014). The excess $\mathrm{P}$ generated within the OMZ seemed to be consumed by non-Redfield processes, i.e., primary production by large phytoplankton found in shelf surface waters, instead of stimulating surface $\mathrm{N}_{2}$ fixation. A possible explanation can be deducted from the optimality-based model of $\mathrm{N}_{2}$ fixation by Pahlow et al. (2013). The model is based on the assumption that natural selection should tend to produce organisms optimally adapted to their environment. The competitive advantage of diazotrophs is most pronounced under conditions of low dissolved inorganic $\mathrm{N}$ and increased dissolved inorganic P (DIN, DIP) availability (Houlton et al., 2008). The ability to compete for DIP is therefore less important at high DIP. Thus, high P concentrations above the ETSP OMZ might actually reduce the selective advantage of diazotrophs compared to non-Redfield primary producers. This could partially explain why cyanobacterial $\mathrm{N}_{2}$ fixers were apparently not stimulated by excess phosphate in surface waters of the abovementioned transect.

\subsection{The impact of changing $N: P$ ratios as a result of ocean deoxygenation: a mesocosm approach}

A series of on-board mesocosm experiments and bioassay incubations were performed in order to identify nutrient limitations in both areas and to specifically address the impact of stoichiometry on primary production. Despite the fundamental differences between the ETNA and ETSP with regard to the $\mathrm{N}$ deficit, the results of short-term mesocosm experiments implied $\mathrm{N}$ limitation of surface plankton communities in both areas (Franz et al., 2012a, b). Further, the partitioning and elemental composition of dissolved and particulate organic matter were investigated. Maximum accumulation of particulate organic carbon (POC) and particulate organic nitrogen (PON) was observed under high $\mathrm{N}$ supply, indicating that primary production was controlled by $\mathrm{N}$ availability. Part of the excess $\mathrm{P}$ was consumed by non-Redfield production, predominantly by diatoms, as also observed from direct monitoring as described above. While particulate $\mathrm{N}: \mathrm{P}$ of the accumulated biomass generally exceeded the supply ratio (Franz et al., 2012b), excess P of the dissolved nutrient pool was channeled into release of dissolved organic phosphorus (DOP) by phytoplankton. These results demonstrated that excess $\mathrm{P}$ upwelled into the surface ocean overlying $\mathrm{O}_{2}$ deficient waters represents a net source for DOP and motivated further dedicated mesocosm experiments in the ETNA to elucidate the fate of DOP. While the direct monitoring and the results of mesocosm studies strongly spoke for a shift to non-Redfield primary production due to changes in $\mathrm{N}$ : $\mathrm{P}$, a general stimulating effect of DOP on $\mathrm{N}_{2}$ fixation has been observed (Meyer et al., 2016). This is in line with a recent modeling study based on large-scale surface datasets of global DON and Atlantic Ocean DOP. Here, the model suggests an important role of DOP for stimulating growth of $\mathrm{N}_{2}$ fixing organisms (Somes and Oschlies, 2015). This model indicates that the marine $\mathrm{N}$ budget is sensitive to DOP, provided that access to the relatively labile DOP pool expands the ecological niche for diazotrophs. Taken together, changes in $\mathrm{N}$ : P may lead to a combination of both non-Redfield primary production and enhanced $\mathrm{N}_{2}$ fixation via DOP.

Besides direct effects of $\mathrm{N}: \mathrm{P}$ ratios, primary production and $\mathrm{N}_{2}$ fixation, due to the comparably high $\mathrm{Fe}$ requirements of the diazotrophs (Gruber and Sarmiento, 1997), are largely influenced by trace metal availability (Mills et al., 2004). From the comparison of the ETNA and ETSP regions, an obvious difference with regard to potentially limiting nutrients is related to the iron $(\mathrm{Fe})$ source: in the ETNA, Saharan dust input contributes $71-87 \%$ of dissolved Fe to the water (Conway and John, 2014). Several studies have highlighted the importance of atmospheric Fe supply to the ETNA (Voss et al., 2004; Mills et al., 2004) as a major factor of primary production. However, a comparable atmospheric Fe source is missing in the ETSP (Baker et al., 2016). Previous studies (Scholz et al., 2014) have identified the ETSP Fe supply as benthic; however, the question of how much Fe is transported from the sediments to the sea surface has not yet been fully clarified.

Results of bioassay incubations and correlation studies demonstrated that primary production and $\mathrm{N}_{2}$ fixation in this region respond significantly to $\mathrm{Fe}$ additions (Dekaezemacker et al., 2013). $\mathrm{N}_{2}$ fixation could be directly limited by inorganic nutrient availability, or indirectly through the stimulation of primary production and the subsequent excretion of dissolved organic matter and/or the formation of microenvironments favorable for heterotrophic $\mathrm{N}_{2}$ fixation (Dekaezemacker et al., 2013).

\subsection{What is the role of $\mathrm{N}_{2}$ fixation for primary production in the ETNA and ETSP?}

Several studies (Voss et al., 2004; Mills et al., 2004; Langlois et al., 2005, 2008) have demonstrated the important role of $\mathrm{N}_{2}$ fixation for surface primary production in ETNA waters. Voss et al. (2004) estimated an average $\mathrm{N}_{2}$ fixation of 24-140 $\mu \mathrm{mol} \mathrm{m}^{-2} \mathrm{~d}^{-1}$, translating into a contribution of 0.1$0.7 \%$ to primary production assuming Redfield stoichiometry on the basis of the rates given in Table 1 . This is below the global average of $5.3 \%$ (Duce et al., 2008), potentially due to the relatively high deposition of reactive N via Saharan dust input.

For the ETSP, $\mathrm{N}_{2}$ fixation was higher compared to the ETNA with rates of $25-657 \mu \mathrm{mol} \mathrm{m}{ }^{-2} \mathrm{~d}^{-1}$ (Dekaezamacker et al., 2013; Löscher et al., 2014), while C fixation was rather lower (Table 1). Here, theoretically, $\mathrm{N}_{2}$ fixation contributes $0.2-7.1 \%$ of $\mathrm{C}$ fixation (Table 1 ). However, while $\mathrm{N}$ loss does not play a role in the ETNA water column (see, e.g., Bange et al., 2010), with the exception of $\mathrm{O}_{2}$-depleted mesoscale eddies (Löscher et al., 2015), high $\mathrm{N}$ loss removes between 1 and 3 orders of magnitude more $\mathrm{N}$ (Kalvelage et 


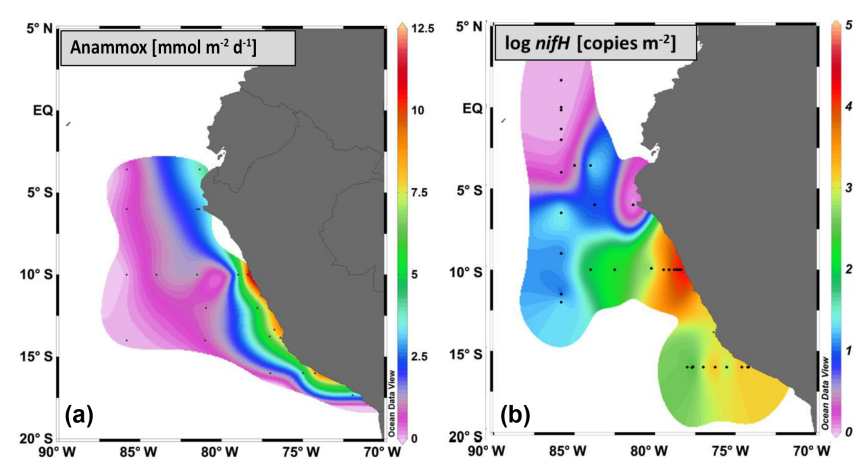

Figure 2. Co-occurrence of anammox as determined by rate measurements and the key functional marker gene for $\mathrm{N}_{2}$ fixation, nifH, in the ETSP OMZ (modified from Kalvelage et al., 2013, and Löscher et al., 2014).

al., 2013; Table 1) than is made available by $\mathrm{N}_{2}$ fixation. This would decrease the contribution of $\mathrm{N}_{2}$ fixation to $\mathrm{C}$ fixation to zero. When comparing $\mathrm{N}_{2}$ fixation to $\mathrm{N}$ loss, it must be considered that first $\mathrm{N}$ loss has only been detected on and close to the shelf, while $\mathrm{N}_{2}$ fixation rates were detectable throughout the OMZ water column (Fig. 2). Second, while $\mathrm{N}_{2}$ fixation is measured via direct $\mathrm{N}_{2}$ incorporation and therefore mirroring in situ rates, $\mathrm{N}$ loss is likely being overestimated as measured following addition of the substrates, which may artificially stimulate the respective process (up to 2-3 orders of magnitude, as discussed in Kalvelage et al., 2013). As a result, an entirely correct budget of $\mathrm{N}_{2}$ fixation vs. $\mathrm{N}$ loss based on rate measurements is difficult to obtain.

In both areas, $\mathrm{N}_{2}$ fixation may, however, be considered important for the productivity of the respective system. Still, given the previously described observations of non-Redfield primary production, the contribution to $\mathrm{C}$ fixation remains to be fully established.

From the comparison of the $\mathrm{N}_{2}$ fixation in the ETNA and ETSP, the question arises of why there is such a strong difference between those systems. A possible explanation may be found in the character of the diazotrophic communities: while the classical view of oceanic $\mathrm{N}_{2}$ fixation mainly attributed to phototrophic cyanobacteria, such as Trichodesmium or Crocosphaera (Capone et al., 1997; Zehr and Turner, 2001), may be mostly true for the ETNA (e.g., Langlois et al., 2005, 2007; Großkopf et al., 2012), a different community of diazotrophs is present in the ETSP.

A growing number of different nifH sequences (the key functional gene of $\mathrm{N}_{2}$ fixation, encoding the $\alpha$ subunit of nitrogenase) detected within the Peruvian OMZ (Bonnet et al., 2013; Dekaezemacker et al., 2013; Fernandez et al., 2011; Löscher et al., 2014; Turk-Kubo et al., 2014) did not belong to common oxygenic phototrophs but instead to some unknown diazotrophic microorganisms that might be specifically adapted to $\mathrm{O}_{2}$-deficient conditions.
These diazotrophs, as well as the extension of their habitat to deeper waters, might be one reason for the possible underestimation of $\mathrm{N}$ gain compared to $\mathrm{N}$ loss in the ocean (Codispoti, 2007). In combination with a novel method for $\mathrm{N}_{2}$ fixation rate measurements (Mohr et al., 2010), up to 6fold higher $\mathrm{N}_{2}$ fixation rates were obtained when considering $\mathrm{N}_{2}$ fixation below the euphotic zone (Großkopf et al., 2012). When extrapolated to all ocean basins this resulted in a $\mathrm{N}_{2}$ fixation rate of $177 \pm 8 \mathrm{Tg} \mathrm{Nyr}^{-1}$, which, depending on the assumed budget, may balance $50-100 \%$ of oceanic $\mathrm{N}$ loss (Codispoti, 2007; Gruber and Sarmiento, 1997).

\subsection{To what extent is $\mathbf{N}_{2}$ fixation in the ETSP OMZ coupled to $\mathbf{N}$ loss?}

Model studies (Deutsch et al., 2007) assume that a N-deficit resulting from $\mathrm{N}$ loss or enhanced $\mathrm{P}$ release (Ingall and Jahnke, 1994) provides a niche for diazotrophs. A coupling of $\mathrm{N}$ loss in OMZs and $\mathrm{N}_{2}$ fixation in overlying surface waters might restore the $\mathrm{N}: \mathrm{P}$ ratio towards Redfield proportions.

In the ETSP OMZ, $\mathrm{N}$ is indeed continuously removed by the anaerobic oxidation of ammonium (anammox) (Francis et al., 2007; Kuypers et al., 2003, 2005; Thamdrup and Dalsgaard, 2002), which has been shown to be the dominant $\mathrm{N}$ loss process in this region (Kalvelage et al., 2013; Lam et al., 2009), as well as in other OMZ waters (off Namibia Kuypers et al., 2005; Peru - Hamersley et al., 2007; and Chile - Thamdrup et al., 2006). Moreover, $\mathrm{N}$ is lost by denitrification (the four-step reduction of $\mathrm{NO}_{3}^{-}$to $\mathrm{N}_{2}$; Devol, 2008), e.g., in the Arabian Sea OMZ (Ward et al., 2009), where denitrification has been identified as the dominant $\mathrm{N}$ loss process. However, off Peru, denitrification was only detectable in connection to sulfidic events (Kalvelage et al., 2013; Schunck et al., 2013).

The prevalence of novel nifH genes and active $\mathrm{N}_{2}$ fixation, derived from samples collected directly in the OMZ waters off Peru, where anammox bacteria were abundant and active (Kalvelage et al., 2013; Löscher et al., 2014), supports the view of a positive feedback between $\mathrm{N}$ loss and $\mathrm{N}$ gain communities (Fig. 3). Evidence for co-occurrence of denitrification and $\mathrm{N}_{2}$ fixation has previously only been documented for an anoxic lake (Halm et al., 2009) and for cyanobacterial aggregates in the Baltic Sea (Klawonn et al., 2015). Recent investigations from Baltic Sea sediments on $\mathrm{N}_{2}$ fixation and diazotrophic abundance in sediments show, however, that a very close spatial link between $\mathrm{N}$ loss and $\mathrm{N}_{2}$ fixation might exist (Bertics et al., 2013). Still, too little is currently known about the interactions among the stoichiometry of inorganic nutrient supply, primary production, $\mathrm{N}_{2}$ fixation, and remineralization under anoxic conditions to allow for a definite characterization of the conditions leading to fixed-nitrogen exhaustion in the OMZs.

This coupling which seems to exist in OMZ waters may in fact have far-reaching consequences: while $\mathrm{N}$ loss may pro- 


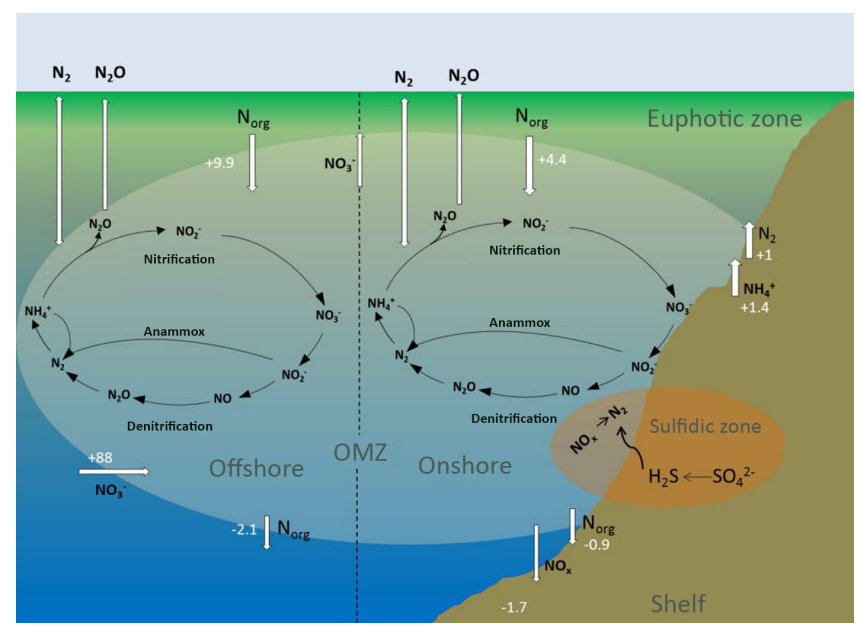

Figure 3. The marine nitrogen $(\mathrm{N})$ cycle with the major onshore and offshore processes in the ETSP OMZ, modified from Kalvelage et al. (2013). Numbers indicate fluxes of $\mathrm{N}\left(\mathrm{Tg} \mathrm{yr}^{-1}\right)$.

vide a niche for $\mathrm{N}_{2}$ fixation, model studies suggest that denitrification of $\mathrm{N}_{2}$ fixation-derived organic matter may lead to a net $\mathrm{N}$ loss that further stimulates $\mathrm{N}_{2}$ fixation, because $120 \mathrm{~mol}$ of nitrate per mole of phosphorus is used to remineralize Redfield organic matter via denitrification (Landolfi et al., 2013). In contrast, $\mathrm{N}_{2}$ fixation fixes only $16 \mathrm{~mol}$ of $\mathrm{N}$ (per mole of P). Because of those stoichiometric constraints, any addition of fixed $\mathrm{N}$ to the surface ocean only exacerbates the problem (Canfield, 2006) unless the corresponding primary production is prevented from being remineralized in the underlying OMZ (Landolfi et al., 2013). Indeed, Lipschultz et al. (1990) stated that $\mathrm{N}$ loss in the ETSP OMZ is high enough to respire all produced organic material. Only by spatial or temporal decoupling of $\mathrm{N}_{2} \mathrm{Fe}$ limitation or dissolved organic matter cycling may the $\mathrm{N}$ inventory stabilize; otherwise, the OMZ would become completely void of fixed inorganic N. Whether these stoichiometric constraints are valid for anammox as dominant $\mathrm{N}$ loss process instead of denitrification is, however, not clear.

Concerning the stoichiometric aspects of ultimate $\mathrm{N}$ loss from OMZ waters, a to date largely disregarded aspect should be taken into consideration: as shown for the Gotland Basin (Jilbert et al., 2011), enhanced preferential P release from organic matter remineralization was quantitatively important for creating a $\mathrm{N}$ deficit. This preferential $\mathrm{P}$ release was present in the water column and was further increased under $\mathrm{O}_{2}$-depleted, reduced conditions. Although the quantitative contribution to the $\mathrm{N}$ deficit in the ETSP is not yet entirely clear, it may act as a factor decoupling the "vicious" cycle between $\mathrm{N}_{2}$ fixation and $\mathrm{N}$ loss (Landolfi et al., 2013), because it may shift the abovementioned stoichiometric constraints.

\subsection{Factors determining $\mathrm{N}$ loss}

The net rate of $\mathrm{N}$ loss in OMZs is determined by the balance of remineralization of sinking particulate organic carbon (POC) and $\mathrm{O}_{2}$ supply to the OMZ. Interestingly, recent studies have attributed the dominance of either anammox or denitrification in a certain environment to organic matter composition and availability (Babbin et al., 2014). While the supply of $\mathrm{O}_{2}$ is mostly determined by physical transport, the rate of $\mathrm{N}$ loss depends on the activity of the bacteria responsible for denitrification and anammox as well as the POC export and sinking velocity.

The intensity of this feedback may be overestimated in current biogeochemical models, owing to spurious nutrient trapping (Dietze and Loeptien, 2013). The extent of the coupling between primary production at the surface and denitrification in the $\mathrm{OMZ}$, and hence the strength of the positive feedback, is a strong function of the elemental $(\mathrm{C}: \mathrm{N}: \mathrm{P})$ stoichiometry of the exported primary production. Phytoplankton $\mathrm{C}: \mathrm{N}: \mathrm{P}$ stoichiometry in turn is influenced by the stoichiometry of inorganic nutrients (Franz et al., 2012a, b). Recently developed process models of primary production and $\mathrm{N}_{2}$ fixation (Pahlow et al., 2013; Pahlow and Oschlies, 2013) specifically address the response of phytoplankton elemental stoichiometry to ambient nutrient concentrations and light.

It is generally assumed that both zooplankton and heterotrophic bacteria vary much less in their elemental stoichiometry than phytoplankton (e.g., Touratier et al., 2001). In both cases, the heterotrophs appear to respond to variable nitrogen content in their food by regulating their gross growth efficiency for carbon (Anderson and Williams, 1998; Kiørboe, 1989). In OMZ regions, this implies that strong nutrient limitation in the surface ocean, which is associated with high $\mathrm{C}: \mathrm{N}$ ratios in primary producers (e.g., data used in Pahlow et al., 2013), should intensify denitrification in the $\mathrm{OMZ}$ relative to the export flux from the surface. Higher surface nutrient concentrations would then be expected to reduce $\mathrm{C}: \mathrm{N}$ ratios in the export flux and hence have a somewhat mitigating effect. Since denitrification and anammox in the OMZ cause lower nitrate concentrations in upwelled waters, the variable stoichiometry of phytoplankton could add to the positive feedback between denitrification and $\mathrm{N}_{2}$ fixation by increasing $\mathrm{C}: \mathrm{N}$ ratios in response to decreasing surface nitrate concentrations.

Combined ${ }^{15} \mathrm{~N}$-incubation experiments and functional gene expression analyses indicate that anammox in the Peruvian OMZ benefits from other $\mathrm{N}$-cycling processes for reactive substrates (Kalvelage et al., 2011). Excretion of ammonium and other reduced $\mathrm{N}$ compounds by diel vertical migrators has also been proposed (Bianchi et al., 2014), but recent experiments indicate that ammonium excretion of diel vertical migrators is strongly reduced at anoxia (Kiko et al., 2015, 2016). Additionally, anammox activity has been described to depend on export of organic matter (Kalvelage et al., 2013), potentially resulting from the availability of am- 
monium recycled from particulate organic N (Ganesh et al., 2015). In the absence of significant denitrification, these results indicate that anammox relies on $\mathrm{NH}_{4}^{+}$oxidation and $\mathrm{NO}_{3}^{-}$reduction as $\mathrm{NO}_{2}^{-}$source. Further, $\mathrm{NH}_{4}^{+}$may be derived from remineralization of organic matter via $\mathrm{NO}_{3}^{-}$reduction with a possibly important role of microaerobic respiration (Kalvelage et al., 2015). The overlap between aerobic and anaerobic $\mathrm{N}$-cycling processes in particular in the coastal shelf waters and the upper part of the OMZ is supportive of microaerobic activity in the OMZ. As dissimilatory nitrate reduction to ammonium (DNRA) was insignificant in the water column during our studies in the ETSP, sedimentary fluxes could be an important ammonium source, particularly for the inner shelf sediments (Bohlen et al., 2011; Kalvelage et al., 2013). However, it has been suggested that sulfate reduction is more widespread in OMZ waters than previously believed and could be responsible for substantial $\mathrm{NH}_{4}^{+}$production (Canfield et al., 2010), and sulfate reducers have been detected in the Peruvian OMZ (Schunck et al., 2013). However, direct evidence for the actual link between sulfate reduction and $\mathrm{NH}_{4}^{+}$production is still missing.

\section{Organic matter export and remineralization in the ETSP OMZ}

\subsection{Sinking of particles}

Knowledge about particle fluxes in areas of tropical OMZs is scarce and predominantly derived from deep moored traps (Honjo et al., 2008) or models (Dale et al., 2015, Table 1). Only a few studies have addressed upper ocean export fluxes and mesopelagic flux attenuation in tropical OMZs (Martin et al. (1987), Devol and Hartnett (2001) and Van Mooy et al. (2002) for the eastern tropical Pacific by means of surface tethered sediment traps; Buesseler et al. (1998) for the Arabian Sea by means of ${ }^{234} \mathrm{Th}$; and Iversen et al. (2010) at the northern edge of the ETNA OMZ by means of particle camera profiling). In the eastern tropical North Pacific (ETNP) (Martin et al., 1987; Van Mooy et al., 2002; Devol and Hartnett, 2001) and the ETSP (Martin et al. 1987; Dale et al., 2015) mesopelagic POC fluxes were less attenuated with depth (Martin curve exponent " $b$ " of 0.32-0.81) compared with the widely used "open-ocean composite" of $b=0.86$ (Martin et al., 1987). Those studies indicate that a greater proportion of the sinking organic matter escapes degradation while sinking through the eastern tropical Pacific OMZ. On the other hand, it has been shown that microbial degradation of organic $\mathrm{N}$ and proteins under suboxia $\left(<20 \mu \mathrm{MO}_{2}\right)$ is not strongly affected (Pantoja et al., 2004, 2009; Van Mooy et al., 2002). In addition, organic matter degradation seems not to be significantly affected by decreased $\mathrm{O}_{2}$ (Dale et al., 2015).

Still, little is known about the microbial controls on the decomposition of organic matter under lower $\mathrm{O}_{2}$ concentrations. Microorganisms are generally considered responsible for most of the remineralization in the ocean. This view is probably justified with respect to carbon, given the high rates of microbial respiration (del Giorgio and Cole, 1998). Owing to the relatively low $\mathrm{N}$ and phosphorous $(\mathrm{P})$ content of dissolved organic matter, however, bacteria may be less important for the remineralization of $\mathrm{N}$ and $\mathrm{P}$ and in fact often compete with phytoplankton for inorganic nutrients in the surface ocean (Anderson and Williams, 1998; Pahlow and Vézina, 2003). Remineralization of $\mathrm{N}$ and $\mathrm{P}$ may thus be largely due to zooplankton activity (Caron et al., 1988; Garber, 1984; Pahlow et al., 2008).

Classically, the most abundant organisms detected in OMZs belong to the Proteobacteria, Bacteroidetes, Thaumarchaeota of the marine group A, Actinobacteria and Planctomycetes (Schunck et al., 2013; Wright et al., 2012). Several candidate clusters have previously been identified, among which are the SAR11, SAR324 and SUP05 clusters (Schunck et al., 2013; Wright et al., 2012). Most investigations of the microbial phylogenetic and functional diversity resort to observing and correlating changes in oxygen concentrations to changes in the microbial phylogenetic diversity. Indeed, several studies, including our own datasets (NCBI accession number: SRP064135), corroborate this idea: a combined statistical analysis of our metagenomic data of the ETSP OMZ (Kalvelage et al., 2015) and datasets from the Chilean OMZ (Canfield et al., 2010; Stewart et al., 2011) has resulted in a partitioning of the OMZ into five different habitats, namely surface, subsurface (defined as below the mixed layer and above waters with $\mathrm{O}_{2}>20 \mu \mathrm{mol} \mathrm{kg}{ }^{-1}$ ), oxyclines, OMZ core $\left(\mathrm{O}_{2}<5 \mu \mathrm{mol} \mathrm{kg}^{-1}\right)$ and sulfidic waters (Fig. 4). High-resolution sampling in the ETNP OMZ has shown that the microbial richness is highest at the base of the euphotic zone and the upper oxycline (Beman and Carolan, 2013), often along with high organic flux, low $\mathrm{O}_{2}$ concentrations and dynamic cycling of $\mathrm{C}, \mathrm{N}$, and sulfur (S). This may be interpreted in a way that the upper oxycline is of higher importance for remineralization than the OMZ.

\subsection{The impact of zooplankton on organic matter export and remineralization}

An important consideration for explaining the lowered flux attenuation in the OMZ could be deducted from the diminished abundance of metazoans in the core of the OMZ. If particles are not repackaged, fed upon, or destroyed, they might sink at greater speeds through the OMZ, which would result in decreased degradation.

Zooplankton and nekton organisms are essential components of the biological pump as they egest packaged organic matter as rapidly sinking fecal pellets. Many zooplankton and nekton species also feed in surface waters during the night and migrate to midwater depth at daybreak to avoid predation (Lampert, 1989) and to conserve energy (McLaren, 1963). This behavior is known as diel vertical migration (DVM) and also contributes to the activity of the biological 


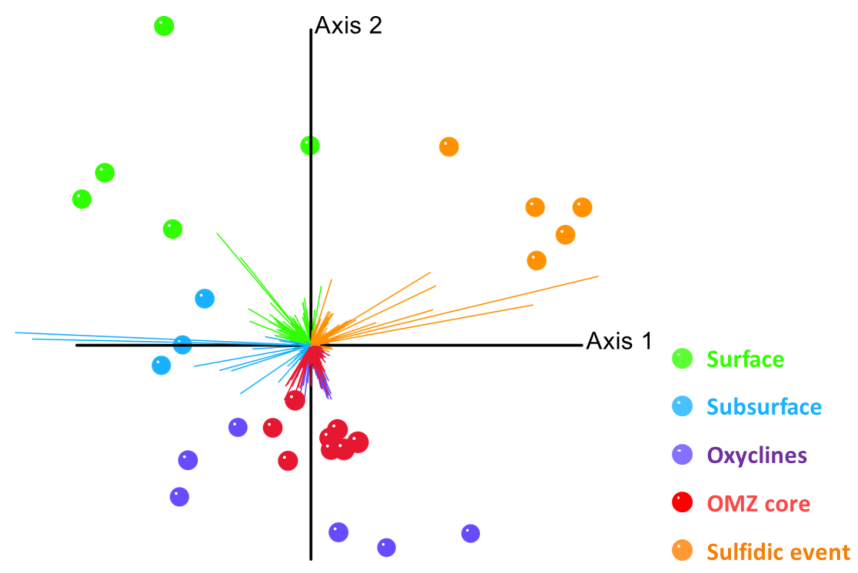

Figure 4. Redundancy analysis ordination model of microbial taxa (vectors) identified from pyrosequencing reads of multiple samples (points) in the ETSP. Spherical $k$-means clustering revealed a 5fold partitioning that reflects distinct OMZ habitats (see legend). Each point is colored according to the cluster that dominated the microbial population in the respective sample.

pump as it enhances the export of organic matter from the photic zone by continued respiration, excretion and egestion in midwater layers (Burd et al., 2010; Hannides et al., 2009; Robinson et al., 2010; Steinberg et al., 2000). In addition to changes in temperature with depth, DVM organisms experience low $\mathrm{O}_{2}$ concentrations during the daytime in $\mathrm{OMZ}$ regions (Brewer and Peltzer, 2009; Paulmier et al., 2011), and $\mathrm{O}_{2}$ concentrations below a certain threshold level can restrict DVM of most zooplankton and nekton (e.g., Hauss et al., 2016). On a regional scale, the upper boundary of the oxycline is the single most critical factor structuring the habitat of most zooplankton organisms in the Peruvian upwelling system (Escribano et al., 2009). Nevertheless, some specifically adapted species are able to downregulate their metabolic activity at low oxygen levels and can remain at OMZ depth (non-migrators) or actively migrate into suboxic or anoxic OMZs (Seibel, 2011; Kiko et al., 2015, 2016).

The abundance and biomass of metazoans living permanently at extremely low oxygen concentrations $<0.6 \mathrm{~mL} \mathrm{~L}^{-1}$ are rather low (Auel and Verheye, 2007; Escribano et al., 2009; Fernández-Álamo and Färber-Lorda, 2006; Saltzmann and Wishner, 1997; Wishner et al., 1998), although animals have evolved physiological (such as metabolic suppression) and/or morphological adaptations (such as increased gill surface area) that allow them to cope temporarily or permanently with $\mathrm{O}_{2}$-depleted conditions (e.g., copepods such as Eucalanus inermis: Flint et al., 1991; euphausiids such as Euphausia mucronata: Antezana, 2009; decapods: Pearcy et al., 1977; cephalopods such as Dosidicus gigas: Rosa and Seibel, 2010; and teleosts: Friedman et al., 2012; Luo et al., 2000). According to Seibel (2011), adaptations to low oxygen levels are needed below approximately $40 \mu \mathrm{mol} \mathrm{O}_{2} \mathrm{~kg}^{-1}$. Strong physiological adaptations thus seem necessary to thrive in the
ETSP OMZ, but not in the ETNA OMZ, where $\mathrm{O}_{2}$ concentrations are normally greater than $40 \mu \mathrm{mol} \mathrm{kg}{ }^{-1}$ (Teuber et al., 2013).

Estimates of zooplankton- and nekton-mediated carbon fluxes in OMZ regions are rare. For the northern Chilean upwelling in the ETSP, Escribano (2009) found that migrations of only two key species (Eucalanus inermis and Euphausia mucronata) contribute approximately $7.2 \mathrm{~g} \mathrm{C} \mathrm{m}^{-2} \mathrm{~d}^{-1}$ to the OMZ through respiration, mortality, and production of fecal pellets within the OMZ. However, these estimates are probably too high, as the reduction of respiration at low oxygen levels (Kiko et al., 2015, 2016) was not accounted for in the calculations. As stated above, a particular role of DVMs for the $\mathrm{N}$ cycle could result from the secretion of ammonium: ammonium is an important nutrient in the anammox reaction which represents nearly $30-50 \%$ of N-loss activity in the OMZ (Codispoti et al., 2001; Emery et al., 1955; Gruber, 2004). Bianchi et al. (2014) suggested that DVMs could supply as much as $30 \%$ of the ammonium for the anammox reaction, assuming no reduction in the rate ammonium excretion under OMZ conditions. This assumption is unlikely to hold, however, as ammonium excretion is, for example, reduced 4-fold in the squat lobster Pleuroncodes monodon (Kiko et al., 2015, 2016) and 6-fold in the euphausiid $E u$ phausia mucronata (Kiko et al., 2015, 2016) upon exposure to anoxia at OMZ temperatures. Thus, the significance of excretion by zooplankton as a source of ammonium for the anammox reaction remains to be established.

\subsection{The impact of viruses on primary production and organic matter feedbacks}

A recent model study quantifying the effect of viruses on ecosystem function in the ocean demonstrated that viruses affect biological productivity and remineralization (Weitz et al., 2015). In line with field studies (Breitbart, 2012), this model showed enhanced organic matter cycling, e.g. by cell lysis. Viruses lyse $\sim 10-40 \%$ of the present prokaryotes every day (Suttle, 2005), which may - besides generally supplying nutrients to the surrounding waters - impact stoichiometry on smaller scales. Specifically, (cyano)phages in the ETSP have been shown to release micronutrients such as $\mathrm{Fe}$ into surrounding waters at an estimated flux of $10 \mathrm{pmol} \mathrm{L}^{-1} \mathrm{~d}^{-1}$ (Poorvin et al., 2004). Likewise, virusinduced bacterial lysis was calculated to contribute $\sim 1-$ $6 \mathrm{Gt} \mathrm{N} \mathrm{a}^{-1}$ to bacterial primary production, which would significantly support phytoplankton production (Shelford et al., 2012). The transfer of nutrients from living organisms into the dissolved phase is called the "viral shunt" (Breitbart, 2012). Besides the "viral shunt", the model showed a reduced transfer of organic material to higher trophic levels, which was interpreted to stabilize primary production. Quantitatively, net primary production was found increased by $\sim 11 \%$ in the presence of viruses. This strongly speaks for a viral impact on the efficiency of the biological pump (Azam, 
1998). On the other side, viruses were shown to influence particle formation and disaggregation through discharging adhesive cell components (Peduzzi and Weinbauer, 1993) and cell lysis (Weinbauer et al., 2011), respectively.

In OMZ waters, highly specific viral communities have been discovered which show unusually low diversity and a low viral-to-microbial ratio (VMR) (Cassman et al., 2012). Specific viruses appear to be only present in OMZ waters as exemplarily shown by genomic studies of uncultivated SUP05 bacteria isolated from the ETSP OMZ (Roux et al., 2014). Interestingly, various genes involved in the cycling of nitrogen and sulfur have also been found in viromes of ETSP waters (see Tables S3 and S4 in Cassman et al., 2012; Roux et al., 2014).

Recent studies analyzing samples from the weaker ETNA OMZ indicated that one of the most abundant archaeal nitrifiers in the ETNA OMZ (Thaumarchaeota, Cand. Nitrosopelagicus brevis) contains several viral genes in its genome arguing that this archaeon is infected by an OMZ-specific hitherto uncharacterized virus (Neulinger and Schmitz, unpublished results), thus confirming earlier studies from the global ocean dataset (Santoro et al., 2015). Considering that Cand. Nitrosopelagicus brevis is most likely the most important producer of the greenhouse gas nitrous oxide in the ETNA and ETSP OMZs (Löscher et al., 2012), these findings add a potential role for greenhouse gas production to the current picture of viruses in the ocean.

\subsection{Physical fluxes of DOM}

Besides particle fluxes and organic matter export via DVM, dissolved organic matter (DOM) transport is due exclusively to physical horizontal and vertical transport processes, induced by mesoscale (horizontal scales of $10-100 \mathrm{~km}$ ) and submesoscale $(100 \mathrm{~m}$ to $10 \mathrm{~km})$ motion and vertical fluxes due to diapycnal mixing. As an example of lateral eddy transport, elevated DOM concentrations have been detected $\left(+11 \mu \mathrm{mol} \mathrm{C} \mathrm{L}{ }^{-1}\right)$ in the Canada Basin within an eddy originating from the shelf region (Mathis et al., 2007). Lasternas et al. (2013) suggested a mechanism for DOM accumulation within anticyclonic eddies, where nutrient downwelling causes a progressive oligotrophication, enhanced cell mortality and lysis, which results in additional DOM release. $\mathrm{Nu}-$ merical model simulations of the Peruvian upwelling regime show that mesoscale dynamics increase the downward and offshore export of nutrients and biomass out of the coastal surface ocean (Lathuiliere et al., 2010). For the understanding of remineralization processes and feedbacks in upwelling systems, a quantification of the material that is lost to the open ocean is critical as it may directly impact the system's productivity. Gruber et al. (2011) found that mesoscale eddy activity in upwelling regimes results in a net reduction of biological productivity. Additionally, submesoscale upwelling filaments can enhance the off-shelf flux of labile DOM (Alvarez-Salgado et al., 2001). Vertical velocities are higher at submesoscale density fronts (Klein and Lapeyre, 2009; Levy et al., 2012; Thomas et al., 2008), which are prominent features in eastern boundary upwelling systems (Durski and Allen, 2005). These vertical velocities often extend to below the mixed layer (Klein et al., 2008), where they can drive sizeable vertical fluxes of solutes. Mahadevan (2014) proposes the subduction of organic-matter-rich surface water into the subsurface layers within submesoscale cold filaments as a new export mechanism, which differs strongly from export via particle sinking. In filaments the organic matter is subducted together with large amounts of $\mathrm{O}_{2}$, which then can directly be used for decomposition of organic matter. Vertical mixing of DOM from the euphotic into to the upper mesopelagic zone is another important transport mechanism in (sub)tropical waters (Hansell, 2002). The Bermuda Atlantic Time-Series Study provides a well-documented example of this process (Carlson et al., 1994). The efficiency of the downward DOM transport depends on the concentration gradient of DOM between the surface layer and the OMZ, as well as on the activity of the microbial population along this gradient. Produced by high primary production in upwelling regions, DOM can accumulate in the euphotic zone with maximum concentrations of $100-300 \mu \mathrm{mol} \mathrm{CL}^{-1}$ off Peru (Franz et al., 2012a; Romankevich and Ljutsarev, 1990). Due to the vicinity of the DOM-rich surface layer to the shallow and sharp oxycline of the Peruvian OMZ, as well as the $\mathrm{O}_{2}$-depleted waters below the oxycline, physical vertical transport may bring large amounts of labile organic matter to the OMZ, where it may be utilized by heterotrophic communities (Hoppe et al., 2000; Hoppe and Ullrich, 1999; Pantoja et al., 2009). DOM supply via (sub)mesoscale vertical transport processes and diapycnal mixing may therefore contribute importantly to sustaining microbial activity in the Peruvian OMZ and may thus largely impact biogeochemical cycles.

\section{Sulfidic events in the ETSP}

Oceanic sulfidic events are extreme cases of anoxia following periods of enhanced primary production and organic matter export. They are understood to mostly originate from sulfide production in sediments (Fig. 5) and have been documented sporadically since the 19th century for the ETSP OMZ (Burtt, 1852; Dugdale et al., 1977). To date sulfidic events have been reported from the eastern tropical South Pacific, the Arabian Sea and the Benguela upwelling system by only a handful of studies and hence our current understanding of their regulation, initiation and termination is still limited. Possible analogs for oceanic events are permanently sulfidic areas in enclosed basins of the Baltic Sea (Brettar et al., 2006; Brettar and Rheinheimer, 1991; Glaubitz et al., 2009), the Black Sea (Glaubitz et al., 2010; Jørgensen et al., 1991; Sorokin et al., 1995), the Cariaco Basin off Venezuela (Hayes et al., 2006; Taylor et al., 2001; Zhang and Millero, 


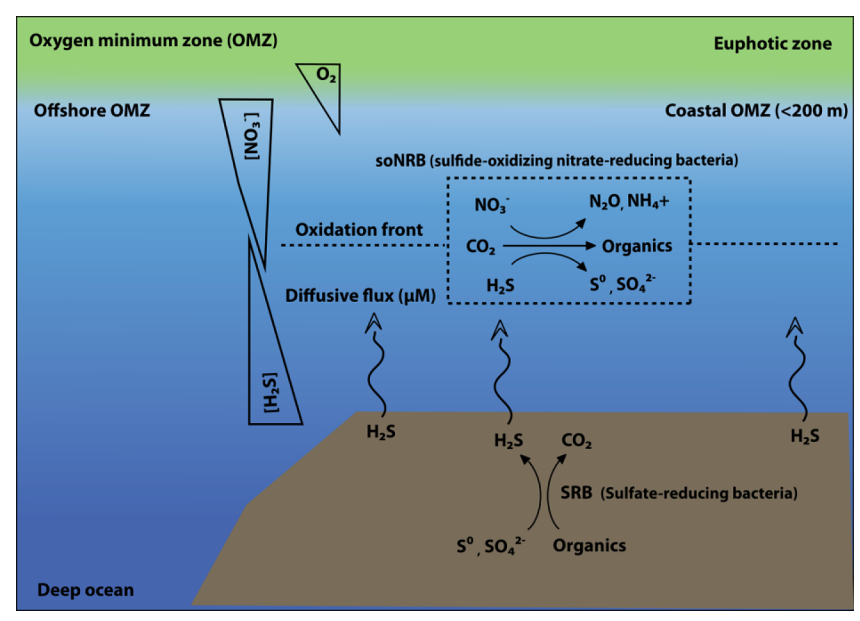

Figure 5. Schematic representation of the dynamics of a sulfidic event occurring in an oxygen minimum zone, e.g. in the ETSP. The sulfide and nitrate fluxes are shown in steady state. Sulfate-reducing bacteria produce sulfide from the sediment while the complementary detoxification process occurs in the water column at overlapping profiles.

1993) and Saanich Inlet in Canada (Tebo and Emerson, 1986; Walsh et al., 2009). Here, sulfide accumulates to millimolar concentrations under $\mathrm{O}_{2}$ and nitrate-free conditions and is released by a diffusive flux into the overlying pelagic water column, where it reaches low micromolar concentrations (Lavik et al., 2009; Schunck et al., 2013). These events are then terminated or detoxified in the pelagic water column by a community of sulfide-oxidizing bacteria. This occurs when sulfide and nitrate are both present thus stimulating sulfideoxidizing nitrate-reducing bacteria (SONRB). SONRB reoxidize sulfide back to sulfate or elemental sulfur while reducing nitrate to either $\mathrm{N}_{2}$ via autotrophic denitrification or $\mathrm{NH}_{4}^{+}$via dissimilatory nitrate reduction to ammonium (Lam and Kuypers, 2011). If nitrate is limiting, sulfur is the more likely end product of sulfide oxidation, which occurs in the following reaction stoichiometry for the denitrification pathway, $2 \mathrm{NO}_{3}^{-}+5 \mathrm{HS}^{-}+7 \mathrm{H}^{+} \rightarrow \mathrm{N}_{2}+5 \mathrm{~S}^{0}+6 \mathrm{H}_{2} \mathrm{O}$. A steady state is reached when the diffusive fluxes $\left(\mathrm{mmol} \mathrm{m}^{-2} \mathrm{~d}^{-1}\right)$ of nitrate and sulfide are in a $1: 2.5$ ratio. If the sulfide flux exceeds the nitrate flux by more than a factor of 2.5 , then sulfide will diffuse into the oxic layer (Lam and Kuypers, 2011). Importantly, the activity of SONRB help to detoxify sulfide to sulfur, preventing it from reaching overlying productive surface waters; hence, most sulfidic events likely go unnoticed (Lavik et al., 2009). However, with the increase in eutrophication and the expansion of OMZs in both the Atlantic and Pacific (Stramma et al., 2008), sulfidic events are expected to become more frequent, as already demonstrated for a time series station in the Baltic Sea (Lennartz et al., 2014).
The first quantitative measurements and detailed profiles of a sulfidic event in the Peruvian upwelling came from Schunck et al. (2013). During RV Meteor cruise M77/3 in January 2009 sulfidic waters covered $>5500 \mathrm{~km}^{2}$ and contained approximately $2.2 \times 10^{4} \mathrm{t}$ of sulfide, making it one of the largest plumes recorded. A total of nine stations were taken along the coastal transect from Lima to Pisco, which showed a $\sim 80 \mathrm{~m}$ thick sulfide-rich layer extending at times just below the oxycline. At this interface oxygen $\left(<1 \mu \mathrm{mol} \mathrm{kg}{ }^{-1}\right)$, nitrate $\left(<1 \mu \mathrm{mol} \mathrm{kg}{ }^{-1}\right)$ and nitrite $\left(2 \mu \mathrm{mol} \mathrm{kg}{ }^{-1}\right)$ profiles overlapped with detectable sulfide concentrations. Stable isotope rate measurements and targeted gene assays using quantitative PCR indicated that various oxidants could have been used by the microbial community to oxidize sulfide at the time of sampling. The most abundant sulfide oxidizers identified from the 16S rRNA diversity belonged to the phylum Proteobacteria within the subphylum $\gamma$-Proteobacteria, including the SUP05/ARCTIC96BD-19 clade, Candidatus Ruthia magnifica, and Candidatus Vesicomyosocius okutanii, but also $\epsilon$ Proteobacteria such as Sulfurovum spp. Metagenomics confirmed that all were capable of sulfide or sulfur oxidation, either with nitrate and oxygen (facultative SONRB) or exclusively with oxygen. Indeed, both subphyla appear to be ubiquitous in other seasonally oxic/anoxic waters and OMZs (Canfield et al., 2010; Lavik et al., 2009; Stevens and Ulloa, 2008; Stewart et al., 2011, 2012; Swan et al., 2011; Walsh et al., 2009). Both $\gamma$ - and $\epsilon$-Proteobacteria members are known chemolithoautotrophs, which assimilate carbon dioxide as the carbon source without the use of sunlight. Subsurface C-assimilation rates were between 0.9 and $1.4 \mu \mathrm{mol} \mathrm{C} \mathrm{L}^{-1} \mathrm{~d}^{-1}$ during this sulfidic event. In this study, "dark" primary production had contributed up to $25 \%$ of the total $\mathrm{CO}_{2}$ fixation in the Peruvian upwelling region at the time of sampling, which is comparable to values observed in the Baltic and Black seas (Schunck et al., 2013, and references therein). Paradoxically, some of these studies showed that measured rates of $\mathrm{CO}_{2}$ assimilation exceed rates possible by chemolithoautotrophic processes alone. Thus, while chemolithoautotrophic $\mathrm{CO}_{2}$ fixation is considered a significant process, the specific activity and main contributors of $\mathrm{CO}_{2}$ fixation during sulfidic events (down to the genus level) still remain unknown.

What is different from our current knowledge of OMZ sulfur cycling is whether the production of sulfide can originate from pelagic waters as well. Simultaneous reduction of different electron acceptors (like $\mathrm{NO}_{3}^{-}, \mathrm{SO}_{4}^{2-}$ and $\mathrm{CO}_{2}$ ) can occur in defined niches where particle aggregates have formed and are sinking through the water column (Wright et al., 2012). These aggregates, more commonly known as marine snow, contain microscale redoxclines under anoxic conditions (Alldredge and Cohen, 1987; Karl and Tilbrook, 1994; Woebken et al., 2007). Moreover, aggregate communities appear to be distinct from bulk water collected samples (Fuchsman et al., 2011). These communities were suggested to have 
active manganese reduction, sulfate reduction and sulfide oxidation at the interior of the aggregates. How much sulfide is generated in the water column during a sulfidic event is not well resolved. Nevertheless, in situ incubation experiments done in the Chilean upwelling have shown the capacity for sulfate reduction in the offshore OMZ occurring under thermodynamically unfavorable nitrate-rich conditions. In separate incubations, measured rates of potential sulfide oxidation were larger than rates of sulfate reduction, indicating that any produced sulfide is immediately re-oxidized (Canfield et al., 2010). The authors intriguingly suggested an active but cryptic sulfur cycle linked to nitrogen cycling in the pelagic OMZ. From a biogeochemical perspective largescale sulfate-reduction coupled to organic matter remineralization releasing inorganic nitrogen could represent a significant supply of ammonium for anammox bacteria.

\section{Trace gas production in $\mathrm{OMZ}$ waters}

The upper $1000 \mathrm{~m}$ of the ocean (including the euphotic zone) is the key region where the production of climate-relevant trace gases such as carbon dioxide $\left(\mathrm{CO}_{2}\right)$, nitrous oxide $\left(\mathrm{N}_{2} \mathrm{O}\right)$, methane $\left(\mathrm{CH}_{4}\right)$ and dimethyl sulfide (DMS) occurs (see, e.g., Liss and Johnson, 2014). While the pathways of $\mathrm{CO}_{2}$ and DMS are dominated by phytoplankton in the oxic euphotic zone, $\mathrm{N}_{2} \mathrm{O}$ and $\mathrm{CH}_{4}$ pathways are dominated by microbial processes at midwater depth (i.e., in the OMZ). This is especially important since some OMZs are connected to coastal upwelling regions where OMZ waters - enriched in both nutrients and trace gases such as $\mathrm{CO}_{2}, \mathrm{~N}_{2} \mathrm{O}$ and $\mathrm{CH}_{4}-$ are brought to the surface, fueling phytoplankton blooms and releasing trace gases to the atmosphere (see, e.g., Capone and Hutchins, 2013). Thus, although they are usually not in direct contact with the atmosphere, OMZs play an important role for oceanic emissions of climate-relevant trace gases (see, e.g., Arévalo-Martínez et al., 2015).

\subsection{Nitrous oxide $\left(\mathrm{N}_{2} \mathrm{O}\right)$ in $\mathrm{OMZ}$}

A comprehensive overview of both nitrous oxide $\left(\mathrm{N}_{2} \mathrm{O}\right)$ distributions and pathways in OMZ has been published in Naqvi et al. (2010). Therefore, we concentrate here on recent findings from the ETNA and ETSP.

$\mathrm{N}_{2} \mathrm{O}$ production in the ocean is dominated by microbial nitrification and denitrification processes. It is formed as a by-product during nitrification and as an intermediate during denitrification. The paradigm that $\mathrm{N}_{2} \mathrm{O}$ is exclusively produced by bacteria has been challenged by the discovery of nitrifying (i.e., $\mathrm{NH}_{4}^{+}$oxidizing) archaea (e.g., Cand. $\mathrm{Ni}$ trosopelagicus brevis; see above) dominating $\mathrm{N}_{2} \mathrm{O}$ production in the ETSP and ETNA (Löscher et al., 2012), which is supported by results of a culture study (Löscher et al., 2012) and a marine microbial enrichment experiment (Santoro et al., 2011). The production of $\mathrm{N}_{2} \mathrm{O}$ by archaea (and bacte- ria) depends on dissolved $\mathrm{O}_{2}$ and increases with decreasing $\mathrm{O}_{2}$ concentrations (Frame and Casciotti, 2010; Löscher et al., 2012). Denitrifying bacteria do not produce $\mathrm{N}_{2} \mathrm{O}$ in the presence of $\mathrm{O}_{2}\left(>10 \mu \mathrm{mol} \mathrm{kg}{ }^{-1}\right)$; however, when $\mathrm{O}_{2}$ concentrations are approaching $0 \mu \mathrm{mol} \mathrm{kg}{ }^{-1}, \mathrm{~N}_{2} \mathrm{O}$ is consumed during denitrification. There is no $\mathrm{N}_{2} \mathrm{O}$ production under anoxic conditions. The significance of $\mathrm{N}_{2} \mathrm{O}$ production during anammox (Kartal et al., 2007) and DNRA (Giblin et al., 2013) in OMZs (see Sect. 5) remains to be proven.

The detailed investigation of $\Delta \mathrm{N}_{2} \mathrm{O} / \mathrm{AOU}$ (i.e., excess $\mathrm{N}_{2} \mathrm{O}$ /apparent oxygen utilization) and $\Delta \mathrm{N}_{2} \mathrm{O} / \Delta^{15} \mathrm{NO}_{3}^{-}$relationships from the ETNA and ETSP revealed two facts (Ryabenko et al., 2012): (i) the lower $\mathrm{O}_{2}$ concentrations found in the core of the OMZ of the ETSP $(<5 \mu \mathrm{mol} \mathrm{kg}-1)$ favor $\mathrm{N}_{2} \mathrm{O}$ consumption by denitrification, which is not observed in the ETNA because of its comparably high $\mathrm{O}_{2}$ concentrations, and (ii) the maximum observed $\mathrm{N}_{2} \mathrm{O}$ concentrations were higher in the ETSP than in the ETNA. This is in line with the results of two model studies of $\mathrm{N}_{2} \mathrm{O}$ in the ETSP by Zamora et al. (2012) and Cornejo and Farias (2012), which suggested that the switching point between $\mathrm{N}_{2} \mathrm{O}$ production and $\mathrm{N}_{2} \mathrm{O}$ consumption occurs at higher $\mathrm{O}_{2}$ concentration $\left(\sim 8-10 \mu \mathrm{mol} \mathrm{kg}^{-1}\right)$ than previously thought.

In contrast to the open ocean, OMZs in coastal (i.e., shelf) regions show a higher spatial and temporal variability: seasonally occurring suboxic or even anoxic/sulfidic OMZs have been observed in coastal regions worldwide (see, e.g., Diaz and Rosenberg, 2008). One of the most prominent areas where widespread sulfidic conditions have been recently observed is the shelf off Peru (Schunck et al., 2013) (Sect. 5). Figure 6 shows the distribution of $\mathrm{N}_{2} \mathrm{O}$, water temperature, nutrients and $\mathrm{H}_{2} \mathrm{~S}$ during the sulfidic event described by Schunck et al. (2013) on the shelf off Peru during December 2008/January 2009. Here, extreme $\mathrm{N}_{2} \mathrm{O}$ concentrations are found at the boundary to the $\mathrm{H}_{2} \mathrm{~S}$ containing bottom waters. No $\mathrm{N}_{2} \mathrm{O}$ is found in the core sulfidic layer. This suggests again that there is a narrow range of low $\mathrm{O}_{2}$ concentrations which is associated with exceptionally high $\mathrm{N}_{2} \mathrm{O}$ production. As soon as the $\mathrm{O}_{2}$ concentrations are close to zero (anoxic/sulfidic conditions), $\mathrm{N}_{2} \mathrm{O}$ production turns into $\mathrm{N}_{2} \mathrm{O}$ consumption. Similar $\mathrm{N}_{2} \mathrm{O}$ distributions during anoxic/sulfidic events were found off the west coast of India, in the Gotland Deep (central Baltic Sea) and in Saanich Inlet (Brettar and Rheinheimer, 1991; Cohen, 1978; Naqvi et al., 2000). Brettar and Rheinheimer (1991) suggested a close coupling between $\mathrm{H}_{2} \mathrm{~S}$ oxidation and $\mathrm{NO}_{3}^{-}$reduction in a narrow layer where $\mathrm{NO}_{3}^{-}$and $\mathrm{H}_{2} \mathrm{~S}$ coexist. This is in line with recent findings from the anoxic event off Peru by Schunck et al. (2013) and similar to the suggestion of a cryptic sulfur cycle where sulfate reduction is coupled to rapid $\mathrm{H}_{2} \mathrm{~S}$ oxidation by $\mathrm{NO}_{3}^{-}$proposed for the $\mathrm{OMZ}$ off Chile by Canfield et al. (2010). 

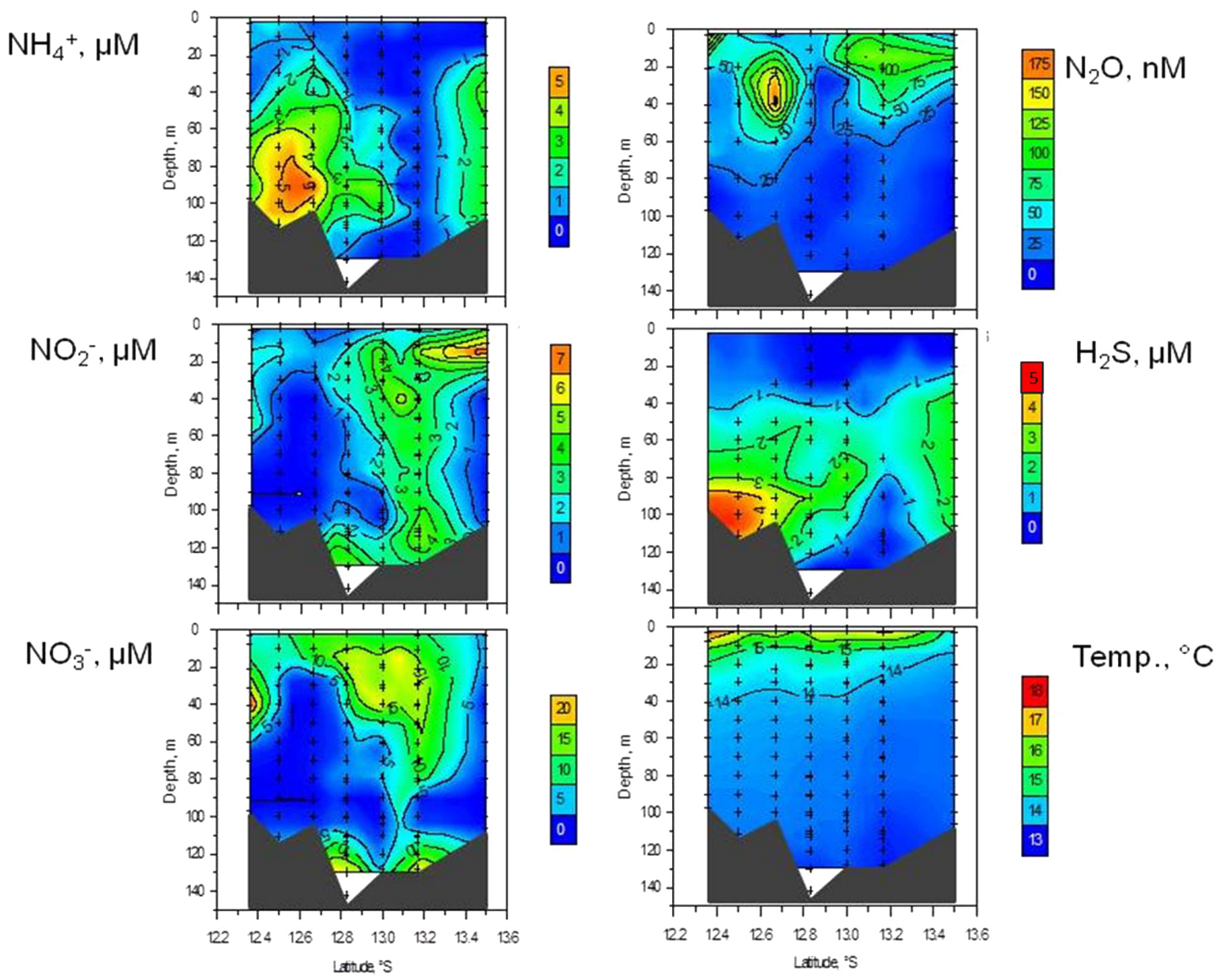

Figure 6. Distributions of $\mathrm{N}_{2} \mathrm{O}, \mathrm{NH}_{4}^{-}, \mathrm{NO}_{2}^{-}, \mathrm{NO}_{3}^{-}, \mathrm{H}_{2} \mathrm{~S}$, and water temperature during December 2008/January 2009 (R/V Meteor cruise $\mathrm{M} 77 / 3$ ) on the shelf along the coast of Peru. Max $\mathrm{N}_{2} \mathrm{O}$ concentrations have been detected right above the sulfidic zone, where a sharp oxycline is present and ammonium and nitrate are available.

\subsection{The role of OMZs in trace gas emissions}

In OMZs with $\mathrm{O}_{2}$ concentrations below $20 \mu \mathrm{mol} \mathrm{kg}{ }^{-1}, \mathrm{~N}_{2} \mathrm{O}$ production does not take place in the core of the OMZ. Instead, $\mathrm{N}_{2} \mathrm{O}$ production is found at the oxycline. Exceptionally high $\mathrm{N}_{2} \mathrm{O}$ concentrations have so far only been found in temporarily occurring anoxic/sulfidic regions off Peru/Chile and western India (Farías et al., 2015; Naqvi et al., 2010). Stagnant sulfidic systems such as in the Baltic and Black seas as well as the Cariaco Basin have shown only slightly enhanced $\mathrm{N}_{2} \mathrm{O}$ concentrations at the oxic-anoxic interfaces (Bange et al., 2010, and references therein). This implies that significant pulses of $\mathrm{N}_{2} \mathrm{O}$ emissions to the atmosphere occur only when a shallow coastal system rapidly shifts from oxic to anoxic/sulfidic conditions and vice versa (Bange et al., 2010). This can be explained by a lag of $\mathrm{N}_{2} \mathrm{O}$ reduction by denitrifiers when they switch from oxygen to nitrogen respiration (Codispoti, 2010) or $\mathrm{N}_{2} \mathrm{O}$ production during the reestablishment of nitrification after $\mathrm{O}_{2}$ ventilation (Schweiger et al., 2007).
$\mathrm{CH}_{4}$ production is also tightly connected to OMZs (see overview in Naqvi et al., 2010). Similar to $\mathrm{N}_{2} \mathrm{O}$, upwelling areas are considerable hotspots for $\mathrm{CH}_{4}$ emissions, although organic-material-enriched shallow coastal zones such as estuaries and mangroves or shallow sediments with geological $\mathrm{CH}_{4}$ sources show higher emissions (Bakker et al., 2014).

Since DMS is produced by phytoplankton in the euphotic zone, an accumulation of DMS in OMZs appears unlikely. However, measurements at the Candolim Time-Series Station (CaTS) on the shelf off Goa (India) revealed an unprecedented 40-fold increase in DMS concentrations in the sulfidic layers during an anoxic event (Shenoy et al., 2012). These high concentrations could not be explained by any known pathways and may imply an unknown - most likely microbial - DMS production pathway under anoxic conditions either in the water column or in the underlying sediments (Shenoy et al., 2012). Only recently it was shown that phytoplankton communities exposed to anoxic conditions increase their DMS production significantly (Omori et al., 2015). This implies a potential accumulation of DMS 

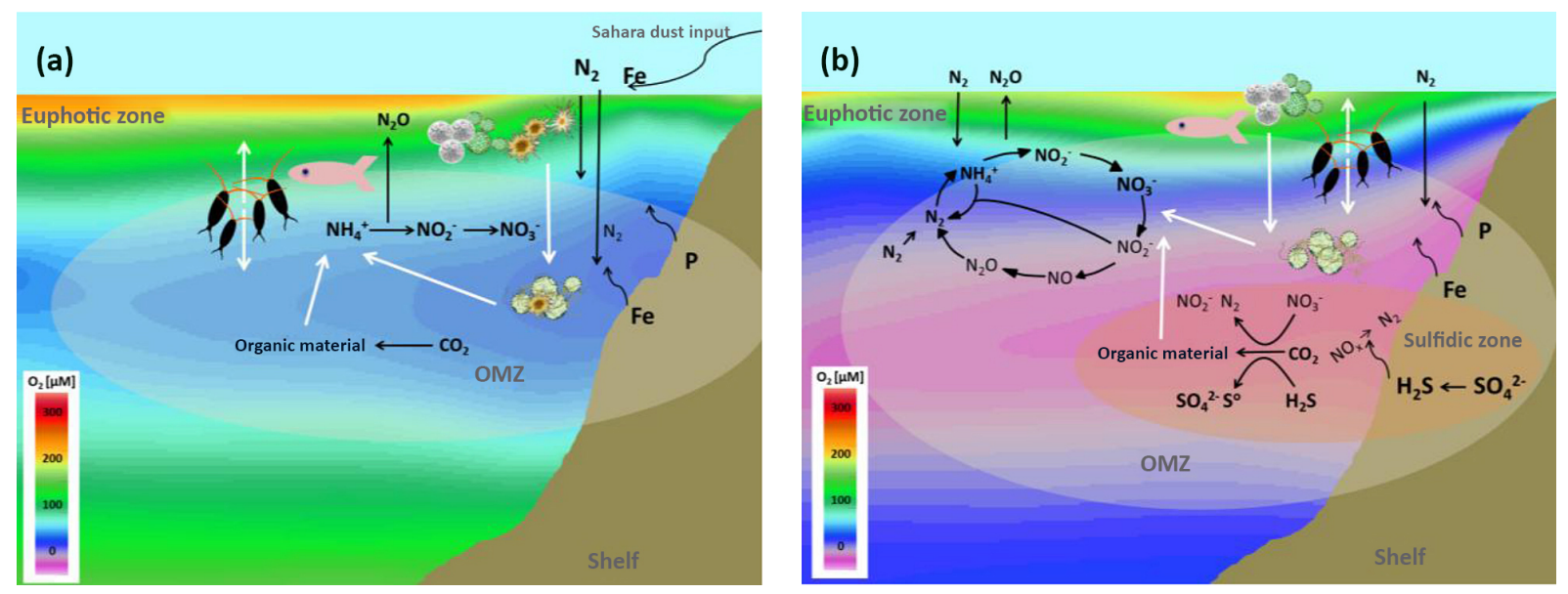

Figure 7. Scheme of the (a) ETNA and (b) ETSP OMZs with major processes identified. The $\mathrm{O}_{2}$ background is taken from SOPRAN cruise $\mathrm{P} 399$, along $18^{\circ} \mathrm{N}$ in the ETNA, and from SFB754 cruise M77/3, along $10^{\circ} \mathrm{S}$ in the ETSP.

at oxic-anoxic boundaries of coastal OMZs which, in turn, might result in high DMS emissions from shallow coastal zones during anoxic/sulfidic events.

\subsection{Trace gas production in OMZ and environmental changes}

Trace gas production in OMZs is expected to be influenced primarily by deoxygenation (Naqvi et al., 2010; Stramma et al., 2012). It is also well known that eutrophication, warming and supply of limiting nutrients (e.g. iron) will increase subsurface respiration of organic material, which leads to deoxygenation in open-ocean and coastal OMZs (Bijma et al., 2013; Gruber, 2011). Acidification of the upper ocean may result in a decrease in calcium carbonate (produced by calcifying organisms), which can act as ballast material for sinking organic matter. Less ballast means a reduction in the sinking speed of organic particles, which could increase the residence time of organic material and cause higher respiration rates (Riebesell et al., 2009). Ongoing environmental changes such as deoxygenation, eutrophication, warming and acidification have both direct and indirect effects on trace gas production in OMZs. In general, we might expect enhanced production of $\mathrm{N}_{2} \mathrm{O}, \mathrm{CH}_{4}$ and DMS in OMZs because of the ongoing loss of $\mathrm{O}_{2}$.

Deoxygenation in open-ocean and coastal environments may lead, on the one hand, to enhanced $\mathrm{N}_{2} \mathrm{O}$ production when approaching the $\mathrm{N}_{2} \mathrm{O}$ production-consumption switching point (see above), but, on the other hand, when $\mathrm{O}_{2}$ concentrations fall below the switching point this may lead to a consumption of $\mathrm{N}_{2} \mathrm{O}$ (Zamora et al., 2012). Moreover, we do not know whether the frequency of coastal anoxic events will continue to increase and how this may affect the coastal net $\mathrm{N}_{2} \mathrm{O}$ production/consumption. A recent modeling study on the influence of anthropogenic nitrogen aerosol deposition on $\mathrm{N}_{2} \mathrm{O}$ production revealed that the effect is small on a global scale but that the OMZ of the Arabian Sea is especially sensitive to atmospheric nitrogen deposition resulting in an enhanced $\mathrm{N}_{2} \mathrm{O}$ production (Suntharalingam et al., 2012).

\section{Conclusions}

While there is a growing amount of data on primary production and the pelagic $\mathrm{N}$ cycle in and associated with $\mathrm{OMZ}$ waters, quantitative estimates of microbial production and respiration, particularly at ultra-low $\mathrm{O}_{2}$ levels, are still not fully explored. This translates into an uncertainty concerning the origin of the $\mathrm{N}$ deficit. While it had been clearly demonstrated that $\mathrm{N}$ loss processes respond sensitively to minimal changes in $\mathrm{O}_{2}$ (Dalsgaard et al., 2014), a potential uncertainty may result from additional processes, such as preferential P release directly in the water column, may be important to create the $\mathrm{N}$ deficit in the water column. In this context, the character and size of particles were shown important (DeVries et al., 2014), linking P release from particles to the character of $\mathrm{N}$ loss (Babbin et al., 2014). The character of the $\mathrm{N}$ loss/N deficit term is, however, highly important, as it determines the extent of $\mathrm{N}$ depletion of the entire $\mathrm{OMZ}$ due to the above-explained stoichiometric discrepancy between $\mathrm{N}$ loss and $\mathrm{N}_{2}$ fixation. Interestingly, a strong impact of decadal climate variations on respiration rates, primary production and the intensity of $\mathrm{N}$ loss has been described for the South Pacific (Deutsch et al., 2011). This may directly link to the character of $\mathrm{N}$ loss derived from our and other measurements and has to be taken into consideration for future studies.

A coupling via the proposed primary production chain may indeed act in OMZs associated with upwelling systems (an overview of major processes in the ETNA and ETSP is depicted in Fig. 7). The important term of organic matter export, either horizontally or vertically, needs more dedicated 
investigations: to date, a quantification is missing of DOM supply via (sub)mesoscale vertical transport processes out of the OMZ area and diapycnal mixing sustaining microbial activity in the Peruvian OMZ. Further, for POM supply to the OMZ, DVM seems to play a key role, despite some quantitative uncertainties. Although some organisms performing DVM have certain strategies to cope with anoxic conditions, mostly by down-regulating their aerobic metabolism, there are limits for zooplankton and nekton. Thus, a reduction of OM export by DVM may result in a further expansion and deoxygenation of OMZs. Deutsch et al. (2014) describe in this context that a decrease in the habitat caused by global warming and ocean deoxygenation increases competition among species and may even result in a loss of metabolic functionality by $20 \%$.

A quantification of DOM and POM import and export rates to and from the ETNA is currently not available; an extensive discussion of POC dynamics from the ETSP OMZs is provided in this issue (Dale et al., 2015). However, information on the character of microbial processes responsible for POM degradation within the OMZ is missing. First studies (e.g., Ganesh et al., 2014, 2015) indicate a key role of particulate organic matter acting as microniches for microbes and thus a host for certain processes such as microaerobic respiration in OMZ waters. By containing strong redox gradients in relatively narrow proximity, and by providing nutrients and trace metals, particles might strongly influence biogeochemical cycles. It is well known that a pronounced $\mathrm{POM}$ /particle-enriched turbid layer (a so-called intermediate nepheloid layer) exists in the core of OMZs adjacent to coastal upwelling regions, such as those found off Peru, Mauritania and the Arabian Sea (see, e.g., Stramma et al., 2013; Naqvi et al., 1993; Fischer et al., 2009).

With regard to sulfidic events, which represent the lower limit of anoxia, the positive feedback coupling could be thought to stabilize itself: while a direct toxic effect of $\mathrm{H}_{2} \mathrm{~S}$ on primary production is mostly mitigated by the respective detoxifying community, decoupling of the supply of benthic nutrients to the sea surface might decrease primary production. This may be of particular importance in areas such as the ETSP, where the benthic supply of, for example, trace metals is dominant. Resulting decreased respiration in the OMZ could be thought to subsequently lead to regeneration to non-sulfidic, less pronounced anoxia, which may stabilize the OMZ to a certain extent. However, whether this hypothesis is valid needs to be resolved.

A critical consequence of ocean deoxygenation is visible from the comparison of the ETSP and ETNA regions: massive supersaturation of $\mathrm{N}_{2} \mathrm{O}$, connected to sulfidic plumes, has been detected repeatedly in the ETSP. OMZs are important sites of enhanced production of climate relevant trace gases such as $\mathrm{N}_{2} \mathrm{O}, \mathrm{CH}_{4}$, and DMS. $\mathrm{N}_{2} \mathrm{O}$ production is significantly enhanced at oxic-anoxic boundaries of OMZs and we suggest that it mainly results from habitat compression, where in extreme cases (such as sulfidic events, sharpening gradients) nitrification and denitrification can occur simultaneously. Maximum $\mathrm{N}_{2} \mathrm{O}$ concentrations and subsequent emissions to the atmosphere have been observed in dynamic coastal systems that rapidly shift from oxic to anoxic conditions and vice versa. Although OMZs are usually not in direct contact with the atmosphere, their vicinity to coastal upwelling systems plays an important role for oceanic emissions of climate-relevant trace gases such as $\mathrm{N}_{2} \mathrm{O}, \mathrm{CH}_{4}$, and DMS with potential feedbacks on global warming, which then may again impact on ocean deoxygenation. Our studies from the ETSP (Arévalo-Martínez, 2015, 2016; Kock et al., 2016) confirm intense production of $\mathrm{N}_{2} \mathrm{O}$ in the coastal upwelling. This is in line with an increase in $\mathrm{N}_{2} \mathrm{O}$ production from OMZ areas as concluded from forced climate models. However, the same model describes a global decrease in $\mathrm{N}_{2} \mathrm{O}$ formation by $4-12 \%$, mostly linked to the western basins of the Pacific and Atlantic oceans (Martinez-Rey et al., 2015).

Marine ecosystems and biogeochemical cycles are increasingly impacted by a growing number of stress factors, some of which act locally, such as eutrophication and pollution, while others act globally. Global stressors are associated with anthropogenic carbon dioxide $\left(\mathrm{CO}_{2}\right)$ emissions and affect the ocean either directly through $\mathrm{CO}_{2}$-induced acidification or indirectly through climate-change-induced ocean warming and deoxygenation (Ciais et al., 2013). How these stressors will impact marine ecosystems and biogeochemistry, individually or in combination, is still largely unknown.

Ocean warming, acidification and deoxygenation occur globally and simultaneously, although with distinct regional differences. Through increased stratification and decreased nutrient supply to the surface layer, ocean warming is expected to decrease the biological production in the already stratified low to midlatitudes.

While research on ocean warming is relatively advanced, far less is known about the impacts of ocean acidification and deoxygenation on marine organisms and ecosystems. Because the three stressors have mostly been studied in isolation, knowledge on the combined effects of two or more of them is scarce. In principle, additive, synergistic (more than additive) and antagonistic (less than additive, i.e., compensatory) interactions of effects are possible, but it is impossible to judge a priori what the combined effects will be. One example of a synergistic effect is that of ocean acidification narrowing the thermal tolerance window of some organisms, amplifying the impact of warming (Pörtner and Farrell, 2008). However, we consider interactions among stressors in marine communities largely understudied.

\section{Outlook}

Major issues remaining unresolved, in addition to those highlighted above, concern (1) a mechanistic understanding of organic matter degradation and nutrient cycling at low or variable oxygen concentrations in the water column and the 
role of DVM for organic matter supply to the OMZ, (2) the sensitivities of heterotrophic microbes and their sensitivity to low-oxygen conditions, and (3) biogeochemical feedback processes in oxygen minimum zones and their impacts on local to global scales.

Future studies in the framework of the SFB754 will combine measurements of particle flux, zooplankton abundance, microbial activities and $\mathrm{O}_{2}$ concentrations in order to answer the following key questions:

i. What is the effect of low-oxygen conditions (below $20 \mu \mathrm{mol} \mathrm{kg}^{-1}$ ) on organic matter degradation, and what is the partitioning between DOM and POM in OMZ waters?

ii. How do the rates of nutrient cycling and loss in OMZs relate to particles and associated microniches?

iii. What are the rates of oxygen supply and consumption in the upper OMZ, and what is regulating respiration rates?

iv. Do small-scale processes (e.g. viral lysis) affect fluxes on larger scales, and how can models represent these important processes?

Acknowledgements. We thank IMARPE and INDP for close collaboration and support. We further thank the authorities of Peru, Cape Verde and Mauritania for the permission to work in their territorial waters. We acknowledge the support of the captains and crews of R/V Meteor and the chief scientists. We thank A. Dale for discussion of the benthic perspective of the manuscript. Financial support for this study was provided by the DFG Sonderforschungsbereich 754 (www.sfb754.de), the Max Planck Society (MPG) and the European Union (Marie Curie IEF to C. R. Löscher, grant \#704272).

Edited by: B. Currie

\section{References}

Alldredge, A. L. and Cohen, Y.: Can microscale chemical patches persist in the sea? Microelectrode study of marine snow, fecal pellets, Science, 235, 689-691, 1987.

Alvarez-Salgado, X. A., Doval, M. D., Borges, A. V., Joint, I., Frankignoulle, M., Woodward, E. M. S., and Figueiras, F. G.: Off-shelf fluxes of labile materials by an upwelling filament in the NW Iberian Upwelling System, Prog. Oceanogr., 51, 321337, 2001.

Anderson, T. R. and Williams, P. J.: Modelling the seasonal cycle of dissolved organic carbon at Station E1 in the English Channel, Estuar. Coast. Shelf S., 46, 93-109, 1998.

Antezana, T.: Species-specific patterns of diel migration into the Oxygen Minimum Zone by euphausiids in the Humboldt Current Ecosystem, Prog. Oceanogr., 83, 228-236, 2009.
Arévalo-Martínez, D. L., Kock, A., Löscher, C. R., Schmitz, R. A., and Bange, H. W.: Evidence of massive nitrous oxide emissions from the tropical South Pacific Ocean, Nat. Geosci., 8, 530-533, 2015.

Arévalo-Martínez, D. L., Kock, A., Löscher, C. R., Schmitz, R. A., Stramma, L., and Bange, H. W.: Influence of mesoscale eddies on the distribution of nitrous oxide in the eastern tropical South $\mathrm{Pa}-$ cific, Biogeosciences, 13, 1105-1118, doi:10.5194/bg-13-11052016, 2016.

Auel, H. and Verheye, H. M.: Hypoxia tolerance in the copepod Calanoides carinatus and the effect of an intermediate oxygen minimum layer on copepod vertical distribution in the northern Benguela Current upwelling system and the Angola-Benguela, J. Exp. Mar. Biol. Ecol., 352, 234-243, 2007.

Azam, F.: Microbial control of oceanic carbon flux: the plot thickens, Science, 280, 694-696, 1998.

Babbin, A. R., Keil, R. G., Devol, A. H., and Ward, B. B.: Organic Matter Stoichiometry, Flux, and Oxygen Control Nitrogen Loss in the Ocean, Science, 344, 406-408, doi:10.1126/science.1248364, 2014.

Baker, A. R., Thomas, M., Bange, H. W., and Plasencia Sánchez, E.: Soluble trace metals in aerosols over the tropical southeast Pacific offshore of Peru, Biogeosciences, 13, 817-825, doi:10.5194/bg-13-817-2016, 2016.

Bakker, D. C. E., Bange, H. W., Gruber, N., Johannessen, T., Upstill-Goddard, R. C., Borges, A. V., Delille, B., Löscher, C. R., Naqvi, S. W. A., Omar, A. M., and Santana-Casiano, J. M.: Airsea interactions of natural long-lived greenhouse gases $\left(\mathrm{CO}_{2}\right.$, $\mathrm{N}_{2} \mathrm{O}, \mathrm{CH}_{4}$ ) in a changing climate, in: Ocean-Atmosphere Interactions of Gases and Particles, edited by: Liss, P. S. and Johnson, M. T., Springer, Verlag, Heidelberg, 2014.

Bange, H. W., Freing, A., Kock, A., and Löscher, C. R.: Marine Pathways to Nitrous Oxide, in: Nitrous oxide and Climate Change, edited by: Smith, K. A., Earthscan, London, Washington, 2010.

Behrenfeld, M. J. and Falkowski, P. G.: Photosynthetic rates derived from satellite-based chlorophyll concentration, Limnol. Oceanogr., 42, 1-20, 1997.

Beman, J. M. and Carolan, M. T.: Deoxygenation alters bacterial diversity and community composition in the oceans largest oxygen minimum zone, Nat. Commun., 4, 2192-2205, doi:10.1038/ncomms3705, 2013.

Bertics, V. J., Löscher, C. R., Salonen, I., Dale, A. W., Gier, J., Schmitz, R. A., and Treude, T.: Occurrence of benthic microbial nitrogen fixation coupled to sulfate reduction in the seasonally hypoxic Eckernförde Bay, Baltic Sea, Biogeosciences, 10, 1243-1258, doi:10.5194/bg-10-1243-2013, 2013.

Bianchi, D., Babbin, A. R., and Galbraith, E. D.: Enhancement of anammox by the excretion of diel vertical migrators, P. Natl. Acad. Sci. USA, 111, 15653-15658, 2014.

Bijma, J., Portner, H.-O., Yesson, C., and Rogers, A. D.: Climate change and the oceans-what does the future hold?, Mar. Pollut. Bull., 74, 495-505, 2013.

Bohlen, L., Dale, A. W., Sommer, S., Mosch, T., Hensen, C., Noffke, A., Scholz, F., and Wallmann, K.: Benthic Nitrogen Cycling Traversing the Peruvian Oxygen Minimum Zone, Geochim. Cosmochim. Ac., 75, 6094-6111, 2011.

Bonnet, S., Dekaezemacker, J., Turk-Kubo, K. A., Moutin, T., Hamersley, R. M., Grosso, O., Zehr, J. P., and Capone, D. G.: 
Aphotic $\mathrm{N}_{2}$ Fixation in the Eastern Tropical South Pacific Ocean, Plos One, 8, e81265, doi:10.1371/journal.pone.0081265, 2013.

Bopp, L., Resplandy, L., Orr, J. C., Doney, S. C., Dunne, J. P., Gehlen, M., Halloran, P., Heinze, C., Ilyina, T., Séférian, R., Tjiputra, J., and Vichi, M.: Multiple stressors of ocean ecosystems in the 21st century: projections with CMIP5 models, Biogeosciences, 10, 6225-6245, doi:10.5194/bg-10-6225-2013, 2013.

Breitbart, M.: Marine viruses: Truth or dare, Annual Review of Marine Science, 4, 425-448, 2012.

Brettar, I. and Rheinheimer, G.: Denitrification in the Central Baltic - Evidence for $\mathrm{H}_{2}$ s-Oxidation as Motor of Denitrification at the Oxic-Anoxic Interface, Mar. Ecol.-Prog. Ser., 77, 157-169, 1991.

Brettar, I., Labrenz, M., Flavier, S., Botel, J., Kuosa, H., Christen, R., and Hofle, M. G.: Identification of a Thiomicrospira denitrificans-Like Epsilonproteobacterium as a Catalyst for Autotrophic Denitrification in the Central Baltic Sea, Appl. Environ. Microb., 72, 1364-1372, 2006.

Brewer, P. G. and Peltzer, E. T.: Limits to Marine Life, Science, 324, 347-348, 2009.

Buesseler, K. O., Ball, L., Andrews, J., Benitez-Nelson, C., Belastock, R., Chai, F., and Chao, Y.: Upper ocean Export of Particulate Organic Carbon in the Arabian Sea derived from Thorium234, Deep-Sea Res. Pt. II, 45, 2461-2487, 1998.

Burd, A. B., Hansell, D. A., Steinberg, D. K., Anderson, T. R., Aristegui, J., Baltar, F., Beaupre, S. R., Buesseler, K. O., DeHairs, F., Jackson, G. A., Kadko, D. C., Koppelmann, R., Lampitt, R. S., Nagata, T., Reinthaler, T., Robinson, C., Robison, B. H., Tamburini, C., and Tanaka, T.: Assessing the apparent imbalance between geochemical and biochemical indicators of meso- and bathypelagic biological activity: What the @\$\#! is wrong with present calculations of carbon budgets?, Deep-Sea Res. Pt. II, 57, 1557-1571, 2010.

Burtt, J.: On fish destroyed by sulphuretted hydrogen in the Bay of Callao, Am. J. Sci., 2, 433-434, 1852.

Canfield, D. E.: Models of oxic respiration, denitrification and sulfate reduction in zones of coastal upwelling, Geochim. Cosmochim. Ac., 70, 5753-5765, 2006.

Canfield, D. E., Stewart, F. J., Thamdrup, B., De Brabandere, L., Dalsgaard, T., Delong, E. F., Revsbech, N. P., and Ulloa, O.: A Cryptic Sulfur Cycle in Oxygen-Minimum-Zone Waters off the Chilean Coast, Science, 330, 1375-1378, 2010.

Capone, D. G., Zehr, J. P., Paerl, H. W., Bergman, B., and Carpenter, E. J.: Trichodesmium, a globally significant marine cyanobacterium, Science, 276, 1221-1229, 1997.

Capone, D. G. and Hutchins, D. A.: Microbial biogeochemistry of coastal upwelling regimes in a changing ocean, Nat. Geosci., 6, 711-717, 2013.

Carlson, C. A., Ducklow, H. W., and Michaels, A. F.: Annual flux of dissolved organic carbon from the euphotic zone in the Northwestern Sargasso Sea, Nature, 371, 405-408, 1994.

Caron, D. A., Goldman, J. C., and Dennett, M. R.: Experimental demonstration of the roles of bacteria and bacterivorous protozoa in plankton nutrient cycles, Hydrobiologia, 159, 27-40, 1988.

Carr, M. E., Strub, P. T., Thomas, A., and Blanco, J. L.: Evolution of 1996-1999 La Niña and El Niño Conditions Off the Western Coast of South America: A Remote Sensing Perspective, J. Geophys. Res., 107, 3236, doi:10.1029/2001JC001183, 2002.
Cassman, N., Prieto-Davó, A., Walsh, K., Silva, G. G., Angly, F., Akhter, S., Barott, K., Busch, J., McDole, T., Haggerty, J. M., Willner, D., Alarcón, G., Ulloa, O., DeLong, E. F., Dutilh, B. E., Rohwer, F., and Dinsdale, E. A.: Oxygen minimum zones harbour novel viral communities with low diversity, Environ. Microbiol., 14, 3043-3065, doi:10.1111/j.14622920.2012.02891.x, 2012.

Chavez, F. P. and Messie, M.: A comparison of eastern boundary upwelling ecosystems, Prog. Oceanogr., 83, 80-96, 2009.

Ciais, P., Sabine, C., Bala, G., Bopp, L., Brovkin, V., Canadell, J., Chhabra, A., DeFries, R., Galloway, J., Heimann, M., Jones, C., Le Quéré, C., Myneni, R. B., Piao, S., and Thornton, P.: Carbon and Other Biogeochemical Cycles, in: Climate Change 2013: The Physical Science Basis. Contribution of Working Group I to the Fifth Assessment Report of the Intergovernmental Panel on Climate Change, edited by: Stocker, T. F., Qin, D., Plattner, G.K., Tignor, M., Allen, S. K., Boschung, J., Nauels, A., Xia, Y., Bex, V., and Midgley, P. M., Cambridge University Press, Cambridge, United Kingdom and New York, NY, USA, 2013.

Cocco, V., Joos, F., Steinacher, M., Frölicher, T. L., Bopp, L., Dunne, J., Gehlen, M., Heinze, C., Orr, J., Oschlies, A., Schneider, B., Segschneider, J., and Tjiputra, J.: Oxygen and indicators of stress for marine life in multi-model global warming projections, Biogeosciences, 10, 1849-1868, doi:10.5194/bg-10-18492013, 2013.

Codispoti, L. A.: Interesting Times for Marine $\mathrm{N}_{2} \mathrm{O}$, Science, 327 , 1339-1340, 2010.

Codispoti, L. A., Brandes, J. A., Christensen, J. P., Devol, A. H., Naqvi, S. W. A., Paerl, H. W., and Yoshinari, T.: The oceanic fixed nitrogen and nitrous oxide budgets: Moving targets as we enter the anthropocene?, Sci. Mar., 65, 85-105, 2001.

Codispoti, L. A.: An oceanic fixed nitrogen sink exceeding $400 \mathrm{Tg}$ $\mathrm{N} \mathrm{a}^{-1}$ vs the concept of homeostasis in the fixed-nitrogen inventory, Biogeosciences, 4, 233-253, doi:10.5194/bg-4-233-2007, 2007.

Cohen, Y.: Consumption of dissolved nitrous oxide in an anoxic basin, Saanich Inlet, British Columbia, Nature, 272, 235-237, 1978.

Conway, T. M. and John, S. G.: Quantification of dissolved iron sources to the North Atlantic Ocean, Nature, 511, 212-215, 2014.

Cornejo, M. and Farías, L.: Following the $\mathrm{N}_{2} \mathrm{O}$ consumption in the oxygen minimum zone of the eastern South Pacific, Biogeosciences, 9, 3205-3212, doi:10.5194/bg-9-3205-2012, 2012.

Dale, A. W., Sommer, S., Lomnitz, U., Montes, I., Treude, T., Liebetrau, V., Gier, J., Hensen, C., Dengler, M., Stolpovsky, K., Bryant, L. D., and Wallmann, K.: Organic carbon production, mineralisation and preservation on the Peruvian margin, Biogeosciences, 12, 1537-1559, doi:10.5194/bg-12-1537-2015, 2015.

Dalsgaard, T., Stewart, F. J., Thamdrup, B., De Brabandere, L., Revsbech, N. P., Ulloa, O., Canfield, D. E., and DeLong, E. F.: Oxygen at nanomolar levels reversibly suppresses process rates and gene expression in anammox and denitrification in the oxygen minimum zone off Northern Chile, mBio, 5, e01966-14, doi:10.1128/mBio.01966-14, 2014.

Dekaezemacker, J., Bonnet, S., Grosso, O., Moutin, T., Bressac, M., and Capone, D. G.: Evidence of active dinitrogen fixation in surface waters of the eastern tropical South Pacific during El Nino 
and La Nina events and evaluation of its potential nutrient controls, Global Biogeochem. Cy., 27, 768-779, 2013.

del Giorgio, P. A. and Cole, J. J.: Bacterial growth efficiency in natural aquatic systems, Annu. Rev. Ecol. Syst., 29, 503-541, 1998.

Deutsch, C., Sarmiento, J. L., Sigman, D. M., Gruber, N., and Dunne, J. P.: Spatial coupling of nitrogen inputs and losses in the ocean, Nature, 445, 163-167, 2007.

Deutsch, C., Brix, H., Ito, T., Frenzel, H., and Thompson, L.: Climate forcing of ocean hypoxia, Science, 333, 336-339, 2011.

Deutsch, C., Berelson, W., Thunell, R., Weber, T., Tems, C., McManus, J., Crusius, J., Ito, T., Baumgartner, T., Ferreira, V., Mey, J., and van Geen, A.: Centennial changes in North Pacific anoxia linked to tropical trade winds, Science, 345, 665-668, 2014.

Devol, A. H.: Denitrification including anammox, in: Nitrogen in the Marine Environment, 2nd Edn., edited by: Capone, D. G., Bronk, D. A., Mulholland, M. R., and Carpenter, E. J., Elsevier, Amsterdam, 2008.

Devol, A. H. and Hartnett, H. E.: Role of the oxygen minimum zone in transfer of organic carbon to the deep ocean, Limnol. Oceanogr., 46, 1684-1690, 2001.

DeVries, T., Liang, J.-H., and Deutsch, C.: A mechanistic particle flux model applied to the oceanic phosphorus cycle, Biogeosciences, 11, 5381-5398, doi:10.5194/bg-11-5381-2014, 2014.

Diaz, R. J. and Rosenberg, R.: Spreading dead zones and consequences for marine ecosystems, Science, 321, 926-929, 2008.

Dietze, H. and Loeptien, U.: Revisiting "nutrient trapping" in global coupled biogeochemical ocean circulation models, Global Biogeochem. Cy., 27, 265-284, 2013.

Duce, R. A., LaRoche, J., Altieri, K., Arrigo, K. R., Baker, A. R., Capone, D. G., Cornell, S., Dentener, F., Galloway, J., Ganeshram, R. S., Geider, R. J., Jickells, T., Kuypers, M. M., Langlois, R., Liss, P. S., Liu, S. M., Middelburg, J. J., Moore, C. M., Nickovic, S., Oschlies, A., Pedersen, T., Prospero, J, Schlitzer, R., Seitzinger, S., Sorensen, L. L., Uematsu, M., U1loa, O., Voss, M., Ward, B., and Zamora, L.: Impacts of atmospheric anthropogenic nitrogen on the open ocean, Science, 320, 893-897, 2008.

Dugdale, R. C., Goering, J. J., Barber, R. T., Smith, R. L., and Packard, T. T.: Denitrification and Hydrogen Sulfide in the Peru Upwelling Region during 1976, Deep-Sea Res., 24, 601-608, 1977.

Durski, S. M. and Allen, J. S.: Finite-amplitude evolution of instabilities associated with the coastal upwelling front, J. Phys. Oceanogr., 35, 1606-1628, 2005.

Emery, K. O., Orr, W. L., and Rittenberg, S. C.: Nutrient budget in the ocean, in: Essays in the Natural Sciences in Honor of Captain Alan Hanock, University of S. Calif. Press, Los Angeles, 229$310,1955$.

Escribano, R., Hidalgo, P., and Krautz, C.: Zooplankton associated with the oxygen minimum zone system in the northern upwelling region of Chile during March 2000, Deep-Sea Res. Pt. II, 56, 1049-1060, 2009.

Farías, L., Besoain, V., and García-Loyola, S.: Presence of nitrous oxide hotspots in the coastal upwelling area off central Chile: an anlysis of temproral variability based on ten years of a biogeochemiocal time series, Environ. Res. Lett., 10, 044017, doi:10.1088/1748-9326/10/4/044017, 2015.
Fernández-Álamo, M. A. and Färber-Lorda, J.: Zooplankton and the oceanography of the eastern tropical Paci?c: a review, Prog. Oceanogr., 69, 318-359, 2006.

Fernandez, C., Farias, L., and Ulloa, O.: Nitrogen Fixation in Denitrified Marine Waters, Plos One, 6, e20539, doi:10.1371/journal.pone.0020539, 2011.

Fischer, G., Karakas, G., Blaas, M., Ratmeyer, V., Nowald, N., Schlitzer, R., Helmke, P., Davenport, R., Donner, B., Neuer, S., and Wefer, G.: Mineral ballast and particle settling rates in the coastal upwelling system off NW Africa and the South Atlantic, Int. J. Earth Sci., 98, 281-298, 2009.

Flint, M., Drits, A., and Pasternak, A.: Characteristic features of body composition and metabolism in some interzonal copepods, Mar. Biol., 111, 199-205, 1991.

Frame, C. H. and Casciotti, K. L.: Biogeochemical controls and isotopic signatures of nitrous oxide production by a marine ammonia-oxidizing bacterium, Biogeosciences, 7, 2695-2709, doi:10.5194/bg-7-2695-2010, 2010.

Francis, C. A., Beman, J. M., and Kuypers, M. M. M.: New processes and players in the nitrogen cycle: the microbial ecology of anaerobic and archaeal ammonia oxidation, ISME J., 1, 1927, 2007.

Franz, J., Krahmann, G., Lavik, G., Grasse, P., Dittmar, T., and Riebesell, U.: Dynamics and stoichiometry of nutrients and phytoplankton in waters influenced by the oxygen minimum zone in the eastern tropical Pacific, Deep-Sea Res. Pt. I, 62, 20-31, 2012a.

Franz, J. M. S., Hauss, H., Sommer, U., Dittmar, T., and Riebesell, U.: Production, partitioning and stoichiometry of organic matter under variable nutrient supply during mesocosm experiments in the tropical Pacific and Atlantic Ocean, Biogeosciences, 9, 46294643, doi:10.5194/bg-9-4629-2012, 2012b.

Friedman, J. R., Condon, N. E., and Drazen, J. C.: Gill surface area and metabolic enzyme activities of demersal fishes associated with the oxygen minimum zone off California, Limnol. Oceanogr., 57, 1701-1710, doi:10.4319/lo.2012.57.6.1701, 2012.

Fuchsman, C. A., Kirkpatrick, J. B., Brazelton, W. J., Murray, J. W., and Staley, J. T.: Metabolic strategies of free-living and aggregate-associated bacterial communities inferred from biologic and chemical profiles in the Black Sea suboxic zone, FEMS Microbiol. Ecol., 78, 586-603, 2011.

Ganesh, S., Parris, D. J., DeLong, E. F., and Stewart, F. J.: Metagenomic analysis of size-fractionated picoplankton in a marine oxygen minimum zone, ISME J., 8, 187-211, doi:10.1038/ismej.2013.144, 2014.

Ganesh, S., Bristow, L. A., Larsen, M., Sarode, N., Thamdrup, B., and Stewart, F. J.: Size-fraction partitioning of community gene transcription and nitrogen metabolism in a marine oxygen minimum zone, ISME J., 9, 2682-2696. doi:10.1038/ismej.2015.44, 2015.

Garber, J. H.: Laboratory Study of Nitrogen and Phosphorus Remineralization during the Decomposition of Coastal Plankton and Seston, Estuar. Coast. Shelf S., 18, 685-702, 1984.

Giblin, A. E., Tobias, C. R., Song, B., Weston, N., Banta, G. T., and Rivera-Monroy, V. H.: Dissimilatory nitrate reduction to ammonium (DNRA), Oceanography, 26, 124-131, 2013.

Glaubitz, S., Lueders, T., Abraham, W. R., Jost, G., Jürgens, K., and Labrenz, M.: ${ }^{13} \mathrm{C}$-isotope analyses reveal that chemolithoau- 
totrophic Gamma- and Epsilonproteobacteria feed a microbial food web in a pelagic redoxcline of the central Baltic Sea, Environ. Microbiol., 11, 326-337, 2009.

Glaubitz, S., Labrenz, M., Jost, G., and Jürgens, K.: Diversity of active chemolithoautotrophic prokaryotes in the sulfidic zone of a Black Sea pelagic redoxcline as determined by rRNA-based stable isotope probing, FEMS Microbiol. Ecol., 74, 32-41, 2010.

Großkopf, T., Mohr, W., Baustian, T., Schunck, H., Gill, D., Kuypers, M. M. M., Lavik, G., Schmitz, R. A., Wallace, D. W. R., and LaRoche, J.: Doubling of marine dinitrogen-fixation rates based on direct measurements, Nature, 488, 361-364, 2012.

Gruber, N.: The dynamics of the marine nitrogen cycle and its influence on atmospheric $\mathrm{CO}_{2}$ variations, in: The ocean carbon cycle and climate, NATO ASI Series, edited by: Follows, M. and Oguz, T., Kluwer Academic, Dordrecht, 2004.

Gruber, N.: Warming up, turning sour, losing breath: ocean biogeochemistry under global change, Philos. T. R. Soc. A, 369, 19801996, 2011.

Gruber, N. and Sarmiento, J. L.: Global patterns of marine nitrogen fixation and denitrification, Global Biogeochem. Cy., 11, 235266, 1997.

Gruber, N., Lachkar, Z., Frenzel, H., Marchesiello, P., Münnich, M., McWillisams, J. C., Nagai, T., and Plattner, G.: Eddy-induced reduction of biological production in eastern boundary upwelling systems, Nat. Geosci., 4, 787-792, 2011.

Halm, H., Musat, N., Lam, P., Langlois, R., Musat, F., Peduzzi, S., Lavik, G., Schubert, C. J., Sinha, B., LaRoche, J., and Kuypers, M. M. M.: Co-occurrence of denitrification and nitrogen fixation in a meromictic lake, Lake Cadagno (Switzerland), Environ. Microbiol., 11, 1945-1958, 2009.

Hamersley, M. R., Lavik, G., Woebken, D., Rattray, J. E., Lam, P., Hopmans, E. C., Damste, J. S. S., Kruger, S., Graco, M., Gutierrez, D., and Kuypers, M. M. M.: Anaerobic ammonium oxidation in the Peruvian oxygen minimum zone, Limnol. Oceanogr., 52, 923-933, 2007.

Hannides, C. C. S., Landry, M. R., Benitez-Nelson, C. R., Styles, R. M., Montoya, J. P., and Karl, D. M.: Export stoichiometry and migrant-mediated flux of phosphorus in the North Pacific Subtropical Gyre, Deep-Sea Res. Pt. I, 56, 73-88, 2009.

Hansell, D. A.: DOC in the global ocean cycle, in: Biogeochemistry of marine dissolved organic matter, edited by: Hansell, D. A. and Carlson, C. A., Elsevier, 2002.

Hauss, H., Christiansen, S., Schütte, F., Kiko, R., Edvam Lima, M., Rodrigues, E., Karstensen, J., Löscher, C. R., Körtzinger, A., and Fiedler, B.: Dead zone or oasis in the open ocean? Zooplankton distribution and migration in low-oxygen modewater eddies, Biogeosciences, 13, 1977-1989, doi:10.5194/bg-13-1977-2016, 2016.

Hayes, M. K., Taylor, G. T., Astor, Y., and Scranton, M. I.: Vertical distributions of thiosulfate and sulfite in the Cariaco Basin, Limnol. Oceanogr., 51, 280-287, 2006.

Honjo, S., Manganini, S. J., Krishfield, R. A., and Francois, R.: Particulate organic carbon fluxes to the ocean interior and factors controlling the biological pump: A synthesis of global sediment trap programs since 1983, Prog. Oceanogr., 76, 217-285, 2008.

Hoppe, H. G. and Ullrich, S.: Profiles of ectoenzymes in the Indian Ocean: phenomena of phosphatase activity in the mesopelagic zone, Aquat. Microb. Ecol., 19, 139-148, 1999.
Hoppe, H.-G., Ullrich, S., von Bröckel, K., and Sellmer, C.: Bacterial C-demand (mineralization) in the aphotic depths of the Arabian Sea exceeds measured C-fluxes from the euphotic zone, in: Berichte aus dem Fachbereich Geowissenschaften, edited by: Donner, B. and Wefer, G., Universität Bremen, No. 162:51, 2000.

Houlton, B. Z., Wang, Y.-P., Vitousek, P. M., and Field, C. B.: A unifying framework for dinitrogen fixation in the terrestrial biosphere, Nature, 454, 327-330, doi:10.1038/nature07028, 2008.

Ingall, E. and Jahnke, R.: Evidence for enhanced phosphorus regeneration from marine sediments overlain by oxygen depleted waters, Geochim. Cosmochim. Ac., 58, 2571-2575, 1994.

Iversen, M. H., Nowald, N., Ploug, H., Jackson, G. A., and Fischer, G.: High resolution profiles of vertical particulate organic matter export off Cape Blanc, Mauritania: Degradation processes and ballasting effects, Deep-Sea Res. Pt. I, 57, 771-784, 2010.

Jilbert, T., Slomp, C. P., Gustafsson, B. G., and Boer, W.: Beyond the Fe-P-redox connection: preferential regeneration of phosphorus from organic matter as a key control on Baltic Sea nutrient cycles, Biogeosciences, 8, 1699-1720, doi:10.5194/bg-8-16992011, 2011.

Jørgensen, B. B., Fossing, H., Wirsen, C. O., and Jannasch, H. W.: Sulfide oxidation in the anoxic Black Sea chemocline, Deep-Sea Res., 38, 105-120, 1991.

Kalvelage, T., Jensen, M. M., Contreras, S., Revsbech, N. P., Lam, P., Gunter, M., LaRoche, J., Lavik, G., and Kuypers, M. M. M.: Oxygen Sensitivity of Anammox and Coupled N-Cycle Processes in Oxygen Minimum Zones, Plos One, 6, e29299, doi:10.1371/journal.pone.0029299, 2011.

Kalvelage, T., Lavik, G., Lam, P., Contreras, S., Arteaga, L., Löscher, C. R., Oschlies, A., Paulmier, A., Stramma, L., and Kuypers, M. M. M.: Nitrogen cycling driven by organic matter export in the South Pacific oxygen minimum zone, Nat. Geosci., 6, 228-234, 2013.

Kalvelage, T., Lavik, G., Jensen, M. M., Revsbech, N. P., Löscher, C. R., Schunck, H., Desai, D. K., Hauss, H., Kiko, R., Holtappels, M., LaRoche, J., Schmitz, R. A., Graco, M. I., and Kuypers, M. M. M.: Aerobic microbial respiration in oceanic oxygen minimum zone, Plos One, 10, e0133526, doi:10.1371/journal.pone.0133526, 2015.

Karl, D. M. and Tilbrook, B. D.: Production and transport of methane in oceanic particulate organic matter, Nature, 368, 732734, 1994.

Karstensen, J., Stramma, L., and Visbeck, M.: Oxygen minimum zones in the eastern tropical Atlantic and Pacific Oceans, Prog. Oceanogr., 77, 331-350, doi:10.1016/j.pocean.2007.05.009, 2008.

Kartal, B., Kuypers, M. M. M., Lavik, G., Schalk, J., den Camp, H., Jetten, M. S. M., and Strous, M.: Anammox bacteria disguised as denitrifiers: nitrate reduction to dinitrogen gas via nitrite and ammonium, Environ. Microbiol., 9, 635-642, 2007.

Kiko, R., Hauss, H., Dengler, M., Sommer, S., and Melzner, F.: The squat lobster Pleuroncodes monodon tolerates anoxic "dead zone" conditions off Peru, Mar. Biol., 162, 1-9, 2015.

Kiko, R., Hauss, H., Buchholz, F., and Melzner, F.: Ammonium excretion and oxygen respiration of tropical copepods and euphausiids exposed to oxygen minimum zone conditions, Biogeosciences, 13, 2241-2255, doi:10.5194/bg-13-2241-2016, 2016. 
Kiørboe, T.: Phytoplankton growth rate and nitrogen content: implications for feeding and fecundity in a herbivorous copepod, Mar. Ecol.-Prog. Ser., 55, 229-234, 1989.

Klawonn, I., Bonaglia, S., Bruchert, V., and Ploug, H.: Aerobic and anaerobic nitrogen transformation processes in $\mathrm{N}_{2}$-fixing cyanobacterial aggregates, ISME J., 9, 1456-1466, 2015.

Klein, P. and Lapeyre, G.: The Oceanic Vertical Pump Induced by Mesoscale and Submesoscale Turbulence, Annual Review of Marine Science, 1, 351-375, doi:10.1146/annurev.marine.010908.163704, 2009.

Klein, P., Hua, B. L., Lapeyre, G., Capet, X., Le Gentil, S., and Sasaki, H.: Upper ocean turbulence from high-resolution 3D simulations, J. Phys. Oceanogr., 38, 1748-1763, 2008.

Kock, A., Arévalo-Martínez, D. L., Löscher, C. R., and Bange, H. W.: Extreme $\mathrm{N}_{2} \mathrm{O}$ accumulation in the coastal oxygen minimum zone off Peru, Biogeosciences, 13, 827-840, doi:10.5194/bg-13827-2016, 2016.

Körtzinger, A., Schimanski, J., Send, U., und Wallace, D. W. R.:The ocean takes a deep breath, Science, 306, 5700, doi:10.1126/science.1102557, 2004.

Kuypers, M. M. M., Sliekers, A. O., Lavik, G., Schmid, M., Jorgensen, B. B., Kuenen, J. G., Damste, J. S. S., Strous, M., and Jetten, M. S. M.: Anaerobic ammonium oxidation by anammox bacteria in the Black Sea, Nature, 422, 608-611, 2003.

Kuypers, M. M. M., Lavik, G., Woebken, D., Schmid, M., Fuchs, B. M., Amann, R., Jorgensen, B. B., and Jetten, M. S. M.: Massive nitrogen loss from the Benguela upwelling system through anaerobic ammonium oxidation, P. Natl. Acad. Sci. USA, 102, 6478-6483, 2005.

Lam, P. and Kuypers, M. M. M.: Microbial nitrogen cycling processes in oxygen minimum zones, Annu. Rev. Mar. Sci., 3, $317-$ 345, 2011.

Lam, P., Lavik, G., Jensen, M. M., van de Vossenberg, J., Schmid, M., Woebken, D., Gutiérrez, D., Amann, R., Jetten, M. S., and Kuypers, M. M.: Revising the nitrogen cycle in the Peruvian oxygen minimum zone, P. Natl. Acad. Sci. USA, 106, 4752-4757, 2009.

Lampert, W.: The adaptive significance of diel vertical migration of zooplankton, Funct. Ecol., 3, 21-27, 1989.

Landolfi, A., Dietze, H., Koeve, W., and Oschlies, A.: Overlooked runaway feedback in the marine nitrogen cycle: the vicious cycle, Biogeosciences, 10, 1351-1363, doi:10.5194/bg-10-1351-2013, 2013.

Langlois, R. J., LaRoche, J., and Raab, P. A..: Diazotrophic diversity and distribution in the tropical and subtropical Atlantic ocean, Appl. Environ. Microb., 71, 7910-7919, 2005.

Langlois, R. J., Hummer, D., and LaRoche, J.: Abundances and distributions of the dominant nifH phylotypes in the Northern Atlantic Ocean, Appl. Environ. Microb., 74, 1922-1931, 2008.

Lasternas, S., Piedeleu, M., Sangrà, P., Duarte, C. M., and Agustí, S.: Forcing of dissolved organic carbon release by phytoplankton by anticyclonic mesoscale eddies in the subtropical NE Atlantic Ocean, Biogeosciences, 10, 2129-2143, doi:10.5194/bg10-2129-2013, 2013.

Lathuiliere, C., Echevin, V., Levy, M., and Madec, G.: On the role of the mesoscale circulation on an idealized coastal upwelling ecosystem, J. Geophys. Res.-Oceans, 115, C09018, doi:10.1029/2009JC005827, 2010.
Lavik, G., Stuhrmann, T., Bruchert, V., Van der Plas, A., Mohrholz, V., Lam, P., Mussmann, M., Fuchs, B. M., Amann, R., Lass, U., and Kuypers, M. M. M.: Detoxification of sulphidic African shelf waters by blooming chemolithotrophs, Nature, 457, 581584, 2009.

Lennartz, S. T., Lehmann, A., Herrford, J., Malien, F., Hansen, H.P., Biester, H., and Bange, H. W.: Long-term trends at the Boknis Eck time series station (Baltic Sea), 1957-2013: does climate change counteract the decline in eutrophication?, Biogeosciences, 11, 6323-6339, doi:10.5194/bg-11-6323-2014, 2014.

Levy, M., Ferrari, R., Franks, P. J. S., Martin, A. P., and Riviere, P.: Bringing physics to life at the submesoscale, Geophys. Res. Lett., 39, L14602, doi:10.1029/2012GL052756, 2012.

Lipschultz, F., Wofsy, S. C, Ward, B. B., Codispoti, L. A., Friedrich, G., and Elkins, J. W.: Bacterial transformations of inorganic nitrogen in the oxygen-deficient waters of the eastern tropical South-Pacific ocean, Deep-Sea Res., 37, 1513-1541, 1990.

Longhurst, A. R., Sathyendrenath, S., Platt, T., and Caverhill, C.: An est imat ion of global primary product ion in the ocean from satellite radiometer data, J. Plankton Res., 17, 1245-1271, 1995.

Liss, P. S. and Johnson, M. T.: Ocean-Atmosphere Interactions of Gases and Particles, Springer, Heidelberg, 2014.

Löscher, C. R., Kock, A., Könneke, M., LaRoche, J., Bange, H. W., and Schmitz, R. A.: Production of oceanic nitrous oxide by ammonia-oxidizing archaea, Biogeosciences, 9, 2419-2429, doi:10.5194/bg-9-2419-2012, 2012.

Löscher, C. R., Großkopf, T., Desai, F., Gill, D., Schunck, H., Croot, P., Schlosser, C., Neulinger, S. C., Lavik, G., Kuypers, M. M. M., LaRoche, J., and Schmitz, R. A.: Facets of diazotrophy in the oxygen minimum zone off Peru, ISME J., 8, 2180-2192, 2014.

Löscher, C. R., Fischer, M. A., Neulinger, S. C., Fiedler, B., Philippi, M., Schütte, F., Singh, A., Hauss, H., Karstensen, J., Körtzinger, A., Künzel, S., and Schmitz, R. A.: Hidden biosphere in an oxygen-deficient Atlantic open-ocean eddy: future implications of ocean deoxygenation on primary production in the eastern tropical North Atlantic, Biogeosciences, 12, 7467-7482, doi:10.5194/bg-12-7467-2015, 2015.

Luo, J., Ortner, P. B., Forcucci, D., and Cummings, S. R.: Diel vertical migration of zooplankton and mesopelagic fish in the Arabian Sea, Deep-Sea Res. Pt. II, 47, 1451-1473, 2000.

Mahadevan: Ocean science: Eddy effects on biogeochemistry, Nat. Geosci., 506, 168-169, 2014.

Martin, J. H., Knauer, G. A., Karl, D. M., and Broenkow, W. W.: VERTEX - Carbon Cycling in the Northeast Pacific, Deep-Sea Res., 34, 267-285, 1987.

Martinez-Rey, J., Bopp, L., Gehlen, M., Tagliabue, A., and Gruber, N.: Projections of oceanic $\mathrm{N}_{2} \mathrm{O}$ emissions in the 21 st century using the IPSL Earth system model, Biogeosciences, 12, 41334148, doi:10.5194/bg-12-4133-2015, 2015.

Mathis, J. T., Pickart, R. S., Hansell, D. A., Kadko, D., and Bates, N. R.: Eddy transport of organic carbon and nutrients from the Chukchi Shelf: Impact on the upper halocline of the western Arctic Ocean, J. Geophys. Res.-Oceans, 112, C05011, doi:10.1029/2006JC003899, 2007.

McLaren, I. A.: Effects of temperature on growth of zooplankton, and the adaptive value of vertical migration, J. Fish. Res. Board Can., 20, 685-727, 1963.

Meyer, J., Löscher, C. R., Neulinger, S. C., Reichel, A. F., Loginova, A., Borchard, C., Schmitz, R. A., Hauss, H., Kiko, R., and Riebe- 
sell, U.: Changing nutrient stoichiometry affects phytoplankton production, DOP accumulation and dinitrogen fixation - a mesocosm experiment in the eastern tropical North Atlantic, Biogeosciences, 13, 781-794, doi:10.5194/bg-13-781-2016, 2016.

Mills, M. M., Ridame, C., Davey, M., La Roche, J., and Geider, R. J.: Iron and phosphorus co-limit nitrogen fixation in the eastern tropical North Atlantic, Nature, 429, 292-294, 2004.

Mohr, W., Grosskopf, T., Wallace, D. W. R., and LaRoche, J.: Methodological underestimation of oceanic nitrogen fixation rates, Plos One, 5, e12583, doi:10.1371/journal.pone.0012583, 2010.

Naqvi, S. W. A., Kumar, M. D., Narvekar, P. V., Desousa, S. N., George, M. D., and Dsilva, C.: An Intermediate Nepheloid Layer Associated with High Microbial Metabolic Rates and Denitrification in the Northwest Indian-Ocean, J. Geophys. Res.-Oceans, 98, 16469-16479, 1993.

Naqvi, S. W. A., Jayakumar, D. A., Narveka, P. V., Naik, H., Sarma, V. V. S. S., D’Souza, W., Joseph, S., and George, M. D.: Increased marine production of $\mathrm{N}_{2} \mathrm{O}$ due to intensifying anoxia on the Indian continental shelf, Nature, 408, 346-349, 2000.

Naqvi, S. W. A., Bange, H. W., Farías, L., Monteiro, P. M. S., Scranton, M. I., and Zhang, J.: Marine hypoxia/anoxia as a source of $\mathrm{CH}_{4}$ and $\mathrm{N}_{2} \mathrm{O}$, Biogeosciences, 7, 2159-2190, doi:10.5194/bg7-2159-2010, 2010.

Omori, Y., Tanimoto, H., Inomata, S., Wada, S., Thume, K., and Pohnert, G.: Enhancement of dimethylsulfuide production by anoxic stress in natural seawater, Geophys. Res. Lett., 42, 40474053, 2015.

Pahlow, M. and Oschlies, A.: Optimal allocation backs Droop's cell-quota model, Mar. Ecol.-Prog. Ser., 473, 1-5, 2013.

Pahlow, M. and Vézina, A. F.: Adaptive model of DOM dynamics in the surface ocean, J. Mar. Res., 61, 127-146, 2003.

Pahlow, M., Vézina, A. F., Casault, B., Maass, H., Malloch, L., Wright, D. G., and Lu, Y.: Adaptive model of plankton dynamics for the North Atlantic, Prog. Oceanogr., 76, 151-191, 2008.

Pahlow, M., Dietze, H., and Oschlies, A.: Optimality-based model of phytoplankton growth and diazotrophy, Mar. Ecol.-Prog. Ser., 489, 1-16, 2013.

Pantoja, S., Sepulveda, J. S., and Gonzalez, H. E.: Decomposition of sinking proteinaceous material during fall in the oxygen minimum zone off northern Chile, Deep-Sea Res. Pt. I, 51, 55-70, 2004.

Pantoja, S., Rossel, P., Castro, R., Cuevas, L. A., Daneri, G., and Cordova, C.: Microbial degradation rates of small peptides and amino acids in the oxygen minimum zone of Chilean coastal waters, Deep-Sea Res. Pt. II, 56, 1019-1026, 2009.

Pauly, D. and Christensen, V.: Primary production required to sustain global fisheries, Nature, 374, 255-257, 1995.

Paulmier, A., Ruiz-Pino, D., and Garçon, V.: $\mathrm{CO}_{2}$ maximum in the oxygen minimum zone (OMZ), Biogeosciences, 8, 239-252, doi:10.5194/bg-8-239-2011, 2011.

Pearcy, W., Krygier, E., Mesecar, R., and Ramsey, F.: Vertical distribution and migration of oceanic micronekton off Oregon, DeepSea Res., 24, 223-245, 1977.

Peduzzi, P. and Weinbauer, M. G.: The submicron size fraction of seawater containing high numbers of virus particles as bioactive agent in unicellular plankton community successions, J. Plankton Res., 15, 1375-1386, 1993.
Poorvin, L., Rinta-Kanto, J. M., Hutchins, D. A., and Wilhelm, S. W.: Viral release of iron and its bioavailability to marine plankton, Limnol. Oceanogr., 49, 1734-1741, 2004.

Pörtner, H. O. and Farrell, A. P.: Physiology, climate change, Science, 322, 690-692, 2008.

Quiñones, R. A., Gutierrez, M. H., Daneri, G., Aguilar, D. G., Gonzalez, H. E., and Chavez, F. P.: The Humboldt Current System, in: Carbon and Nutrient Fluxes in Continental Margins: A Global Synthesis, edited by: Liu, K.-K., Atkinson, L., Quiñones, R., and Talaue-McManus, L., Springer-Verlag, Berlin, 44-64, 2010.

Riebesell, U., Körtzinger, A., and Oschlies, A.: Sensitivities of marine carbon fluxes to ocean change, P. Natl. Acad. Sci., 106, 20602-20609, 2009.

Robinson, C., Steinberg, D. K., Anderson, T. R., Aristegui, J., Carlson, C. A., Frost, J. R., Ghiglione, J. F., Hernandez-Leon, S., Jackson, G. A., Koppelmann, R., Queguiner, B., Ragueneau, O., Rassoulzadegan, F., Robison, B. H., Tamburini, C., Tanaka, T., Wishner, K. F., and Zhang, J.: Mesopelagic zone ecology and biogeochemistry - a synthesis, Deep-Sea Res. Pt. II, 57, 15041518, 2010.

Romankevich, E. A. and Ljutsarev, S. V.: Dissolved organic carbon in the Ocean, Mar. Chem., 30, 161-178, 1990.

Rosa, R. and Seibel, B. A.: Metabolic physiology of the Humboldt squid, Dosidicus gigas: Implications for vertical migration in a pronounced oxygen minimum zone, Prog. Oceanogr., 86, 72-80, 2010.

Roux, S., Hawley, A. K., Torres Beltran, M., Scofield, M., Schwientek, P., Stepanauskas, R., Woyke, T., Hallam, S. J., and Sullivan, M. B.: Ecology and evolution of viruses infecting uncultivated SUP05 bacteria as revealed by single-cell- and meta-genomics, eLife, 3, e03125, doi:10.7554/eLife.03125, 2014.

Ryabenko, E., Kock, A., Bange, H. W., Altabet, M. A., and Wallace, D. W. R.: Contrasting biogeochemistry of nitrogen in the Atlantic and Pacific Oxygen Minimum Zones, Biogeosciences, 9, 203215, doi:10.5194/bg-9-203-2012, 2012.

Saltzmann, J. and Wishner, K. F.: Zooplankton ecology in the eastern tropical Pacific ozygen minimum zone above a seamout: 2 . Vertical distribution of copepods, Deep-Sea Res. I, 44, 931-954, 1997.

Santoro, A. E., Buchwald, C., McIlvin, M. R., and Casciotti, K. L.: Isotopic Signature of $\mathrm{N}_{2} \mathrm{O}$ Produced by Marine AmmoniaOxidizing Archaea, Science, 333, 1282-1285, 2011.

Santoro, A. E., Dupont, C. L., Richter, R. A., Craig, M. T., Carini, P., McIlvin, M. R., Yang, Y., Orsi, W. D., Moran, D. M., and Saito, M. A.: Genomic and proteomic characterization of "Candidatus Nitrosopelagicus brevis": An ammonia-oxidizing archaeon from the open ocean, P. Natl. Acad. Sci. USA, 112, 1173-1178, doi:10.1073/pnas.1416223112, 2015.

Scholz, F., McManus, J., Mix, A. C., Hensen, C., and Schneider, R. R.: The impact of ocean deoxygenation on iron release from continental margin sediments, Nat. Geosci., 7, 433-437, doi:10.1038/NGEO2162, 2014.

Schunck, H., Lavik, G., Desai, D. K., Großkopf, T., Kalvelage, T., Löscher, C. R., Paulmier, A., Contreras, S., Siegel, H., Holtappels, M., Rosenstiel, P., Schilhabel, M. B., Graco, M., Schmitz, R. A., Kuypers, M. M. M., and LaRoche, J.: Giant Hydrogen Sulfide Plume in the Oxygen Minimum Zone off Peru Supports Chemolithoautotrophy, Plos One, 8, e68661, doi:10.1371/journal.pone.0068661, 2013. 
Schweiger, B., Hansen, H. P., and Bange, H. W.: A time series of hydroxylamine $\left(\mathrm{NH}_{2} \mathrm{OH}\right)$ in the southwestern Baltic Sea, Geophys. Res. Lett., 34, L24608, doi:10.1029/2007GL031086, 2007.

Seibel, B. A.: Critical oxygen levels and metabolic suppression in oceanic oxygen minimum zones, J. Exp. Biol., 214, 326-336, 2011.

Shelford, E. J., Middelboe, M., Møller, E. F., and Suttle, C. A.: Virus-driven nitrogen cycling enhances phytoplankton growth, Aquat. Microb. Ecol., 66, 41-46, 2012.

Shenoy, D. M., Sujith, K. B., Gauns, M. U., Patil, S., Sarkar, A., Naik, H., Narvekar, P. V., and Naqvi, S. W. A.: Production of dimethylsulphide during the seasonal anoxia off Goa, Biogeochemistry, 110, 47-55, 2012.

Somes, C. J. and Oschlies, A. C. G. B.: On the influence of "non-Redfield" dissolved organic nutrient dynamics on the spatial distribution of $\mathrm{N}_{2}$ fixation and the size of the marine fixed nitrogen inventory, Global Biogeochem. Cy., 29, 973-993, doi:10.1002/2014GB005050, 2015.

Sorokin, Y. I., Sorokin, P. Y., Avdeev, V. A., Sorokin, D. Y., and Ilchenko, S. V.: Biomass, Production and Activity of Bacteria in the Black-Sea, with Special Reference to Chemosynthesis and the Sulfur Cycle, Hydrobiologia, 308, 61-76, 1995.

Steinberg, D. K., Carlson, C. A., Bates, N. R., Goldthwait, S. A., Madin, L. P., and Michaels, A. F.: Zooplankton vertical migration and the active transport of dissolved organic and inorganic carbon in the Sargasso Sea, Deep-Sea Res. Pt. I, 47, 137-158, 2000.

Stevens, H. and Ulloa, O.: Bacterial diversity in the oxygen minimum zone of the eastern tropical South Pacific, Environ. Microbiol., 10, 1244-1259, 2008.

Stewart, F. J., Ulloa, O., and DeLong, E. F.: Microbial metatranscriptomics in a permanent marine oxygen minimum zone, Environ. Microbiol., 14, 23-40, 2011.

Stewart, F. J., Ulloa, O., and DeLong, E. F.: Microbial metatranscriptomics in a permanent marine oxygen minimum zone, Environ. Microbiol., 14, 23-40, doi:10.1111/j.14622920.2010.02400.x, 2012.

Stramma, L., Johnson, G. C., Sprintall, J., and Mohrholz, V.: Expanding Oxygen-Minimum Zones in the Tropical Oceans, Science, 320, 655-658, 2008.

Stramma, L., Oschlies, A., and Schmidtko, S.: Mismatch between observed and modeled trends in dissolved upper-ocean oxygen over the last $50 \mathrm{yr}$, Biogeosciences, 9, 4045-4057, doi:10.5194/bg-9-4045-2012, 2012.

Stramma, L., Bange, H. W., Czeschel, R., Lorenzo, A., and Frank, M.: On the role of mesoscale eddies for the biological productivity and biogeochemistry in the eastern tropical Pacific Ocean off Peru, Biogeosciences, 10, 7293-7306, doi:10.5194/bg-10-72932013, 2013.

Suntharalingam, P., Buitenhuis, E., Le Quere, C., Dentener, F., Nevison, C., Butler, J. H., Bange, H. W., and Forster, G.: Quantifying the impact of anthropogenic nitrogen deposition on oceanic nitrous oxide, Geophys. Res. Lett., 39, L07605, doi:10.1029/2011GL050778, 2012.

Suttle, C. A.: Viruses in the sea, Nature, 437, 356-361, 2005.

Swan, B. K., Martinez-Garcia, M., Preston, C. M., Sczyrba, A., Woyke, T., Lamy, D., Reinthaler, T., Poulton, N. J., Masland, E. D. P., Gomez, M. L., Sieracki, M. E., DeLong, E. F., Herndl, G. J., and Stepanauskas, R.: Potential for Chemolithoautotrophy
Among Ubiquitous Bacteria Lineages in the Dark Ocean, Science, 333, 1296-1300, 2011.

Taylor, G. T., Iabichella, M., Ho, T. Y., Scranton, M. I., Thunell, R. C., Muller-Karger, F., and Varela, R.: Chemoautotrophy in the redox transition zone of the Cariaco Basin: A significant midwater source of organic carbon production, Limnol. Oceanogr., 46, 148-163, 2001.

Tebo, B. M. and Emerson, S.: Microbial manganese(II) oxidation in the marine environment: a quantitative study, Biogeochemistry, 2, 149-161, 1986.

Teuber, L., Kiko, R., Seguin, F., and Auel, H. J.: Respiration rates of tropical Atlantic copepods in relation to the oxygen minimum zone, J. Exp. Mar. Biol. Ecol., 448, 28-36, 2013.

Thamdrup, B. and Dalsgaard, T.: Production of $\mathrm{N}_{2}$ through anaerobic ammonium oxidation coupled to nitrate reduction in marine sediments, Appl. Environ. Microb., 68, 1312-1318, 2002.

Thamdrup, B., Dalsgaard, T., Jensen, M. M., Ulloa, O., Farias, L., and Escribano, R.: Anaerobic ammonium oxidation in the oxygen-deficient waters off northern Chile, Limnol. Oceanogr., 51, 2145-2156, 2006.

Thomas, L. N., Tandon, A., and Mahadevan, A.: Submesoscale processes and dynamics, in: Ocean Modeling in an Eddying Regime, edited by: Hecht, M. and Hasumi, H., Geophysical Monograph Series, vol. 177, American Geophysical Union, Washington, DC, 17-38, 2008.

Touratier, F., Field, J. G., and Moloney, C. L.: A stoichiometric model relating growth substrate quality $(\mathrm{C}: \mathrm{N}: \mathrm{P}$ ratios) to $\mathrm{N}: \mathrm{P}$ ratios in the products of heterotrophic release and excretion, Ecol. Model., 139, 265-291, 2001.

Turk-Kubo, K. A., Karamchandani, M., Capone, D. G., and Zehr, J. P.: The paradox of marine heterotrophic nitrogen fixation: abundances of heterotrophic diazotrophs do not account for nitrogen fixation rates in the Eastern Tropical South Pacific, Environ. Microbiol., 16, 3095-3114, 2014.

Van Mooy, B. A. S., Keil, R. G., and Devol, A. H.: Impact of suboxia on sinking particulate organic carbon: Enhanced carbon flux and preferential degradation of amino acids via denitrification, Geochim. Cosmochim. Ac., 66, 457-465, 2002.

Voss, M., Croot, P., Lochte, K., Mills, M., and Peeken, I.: Patterns of nitrogen fixation along $10^{\circ} \mathrm{N}$ in the tropical Atlantic, Geophys. Res. Lett., 31, L23S09, doi:10.1029/2004GL020127, 2004.

Walsh, D. A., Zaikova, E., Howes, C. G., Song, Y. C., Wright, J. J., Tringe, S. G., Tortell, P. D., and Hallam, S. J.: Metagenome of a Versatile Chemolithoautotroph from Expanding Oceanic Dead Zones, Science, 326, 578-582, 2009.

Walsh, J. J.: A carbon budget for overfishing off Peru, Nature, 290, 300-304, 1981.

Ward, B. B., Devol, A. H., Rich, J. J., Chang, B. X., Bulow, S. E., Naik, H., Pratihary, A., and Jayakumar, A.: Denitrification as the dominant nitrogen loss process in the Arabian Sea, Nature, 461, 78-81, 2009.

Weinbauer, M. G., Bonilla-Findji, O., Chan, A. M., Dolan, J. R., Short, S. M., Simek, K., Wilhelm, S. W., and Suttle, C. A.: Synechococcus growth in the ocean may depend on the lysis of heterotrophic bacteria, J. Plankt. Res., 33, 1465-1476, doi:10.1093/plankt/fbr041, 2011.

Weitz, J. S., Stock, C. A., Wilhelm, S. W., Bourouiba, L., Coleman, M. L., Buchan, A., Follows, M. J., Fuhrman, J. A., Jover, L. F., Lennon, J. T., Middelboe, M., Sonderegger, D. L., Suttle, C. A., 
Taylor, B. P., Frede Thingstad, T., Wilson, W. H., and Eric Wommack, K.: A multitrophic model to quantify the effects of marine viruses on microbial food webs and ecosystem processes, ISME J., 9, 1352-1364, 2015.

Wishner, K. F., Gowing, M. M., and Gelfman, C.: Mesozooplankton biomass in the upper $1000 \mathrm{~m}$ in the Arabian Sea: overall seasonal and geographic patterns, and relationship to oxygen gradients, Deep-Sea Res. Pt. II, 45, 2405-2432, 1998.

Woebken, D., Teeling, H., Wecker, P., Dumitriu, A., Kostadinov, I., DeLong, E. F., Amann, R., and Glöckner, F. O.: Fosmids of novel marine planctomycetes from the Namibian and Oregon coast upwelling systems and their cross-comparison with planctomycete genomes, ISME J., 1, 419-435, 2007.

Wright, J. J., Konwar, K. M., and Hallam, S. J.: Microbial ecology of expanding oxygen minimum zones, Nat. Rev. Microbiol., 10, 381-394, 2012.
Zamora, L. M., Oschlies, A., Bange, H. W., Huebert, K. B., Craig, J. D., Kock, A., and Löscher, C. R.: Nitrous oxide dynamics in low oxygen regions of the Pacific: insights from the MEMENTO database, Biogeosciences, 9, 5007-5022, doi:10.5194/bg-9-5007-2012, 2012.

Zehr, J. P. and Turner, P. J.: Nitrogen fixation: Nitrogenase genes and gene expression, in: Methods in Microbiology, Methods in Microbiology, Academic Press Inc, San Diego, Vol. 30, 271-286, 2001.

Zhang, J. Z. and Millero, F. J.: The Chemistry of the Anoxic Waters in the Cariaco Trench, Deep-Sea Res Pt. I, 40, 1023-1041, 1993. 